\title{
İbn Sînâ'nın Atomculuk Eleştirisinin Sonraki Kelâm Atomculuk Tartışmaları Üzerindeki Etkisi
}

"Dhanani, Alnoor. 'The Impact of Ibn Sinnā's Critique of Atomism on Subsequent Kalām Discussions of Atomism'. Arabic Sciences and Philosophy 25 (2015): 79-104.

https:// doi:10.1017/S0957423914000101"

Tercüme

\section{Emine Nur ERDEM}

Arş. Gör., Kahramanmaraş Sütçü İmam Üniversitesi, İlahiyat Fakültesi, Kahramanmaraş/Türkiye Research Assistant, Kahramanmaraş Sütçü İmam University, Faculty of Theology, Kahramanmaraş/Turkey eminenur_erdem34@hotmail.com | http://orcid.org/0000-0001-9568-1643 | ror.org/03gn5cg19

$\begin{array}{rll}\text { Makale Bilgisi } & \text { Article Information } \\ \text { Makale Türü } & \text { Article Type } \\ \text { Tercüme Makale } & \text { Translation } \\ \text { Geliş Tarihi } & \text { Date Recieved } \\ 14 \text { Nisan } 2021 & 14 \text { April } 2021 \\ \text { Kabul Tarihi } & \text { Date Accepted } \\ 14 \text { Haziran } 2021 & 14 \text { June 2021 } \\ \text { Yayın Tarihi } & \text { Date Published } \\ 30 \text { Haziran 2021 } & 30 \text { June 2021 } \\ \text { İntihal } & \text { Plagiarism } \\ \text { tespit edilmemiştir. } & \text { software. No plagiarism detected. } \\ \text { Etik Beyan } & \text { Ethical Statement } \\ \text { Bu makale, iTenticate yazılımı ile taranmısttrintihal } & \text { This article has been scanned with iTenticate } \\ \text { Bu çalışmanın hazırlanma sürecinde bilimsel ve etik } & \text { It is declared that scientific and ethical principles } \\ \text { ilkelere uyulduğu ve yararlanılan tüm çalışmaların } & \text { have been followed while carrying out and writing } \\ \text { kaynakçada belirtildiği beyan olunur (Emine Nur } & \text { this study and that all the sources used have been } \\ \text { Erdem). } & \text { properly cited (Emine Nur Erdem). } \\ \text { CC BY-NC-ND 4.0 lisansı ile lisanslanmıştır. } & \text { Licensed under CC BY-NC-ND 4.0 license. }\end{array}$

Atıf | Cite As

c Dhanani, Alnoor. "ibn Sînâ'nın Atomculuk Eleştirisinin Sonraki Kelâm Atomculuk Tartışmaları Üzerindeki Etkisi”. çev. Emine Nur Erdem. Kader 19/1 (Haziran 2021), 322-346. https://doi.org/10.18317/kaderdergi.915716 


\section{Öz}

Kelâm atomculuğu, filozofların Aristotelesçi doğa felsefesine karşı durmuştur. İbn Sînâ, Şifâ isimli eserinin Fizik kısmında birçok argüman aracılı̆̆ılla kelâm atomculuğunun ayrıntılı bir reddine girişmiştir. Bu argümanlar, kelâma olan bağlllı̆̆ı en iyi ihtimalle asgari düzeyde olan Gazzâlî tarafından sessiz karşılanmıştır. Daha etkili bir cevap, Şehristânî tarafından öne sürülmüş gibi görünmektedir. Ancak onun ayrıntıları, günümüze ulaşan kaynakların eksikliğinden dolayı kabataslak kalmıştır. Entelektüel gelişimi, ỉbn Sînâcılık'a bağlı kalarak onun atom-karşıtı argümanlarına güçlü bir şekilde sahip çıktı̆̆1 evre ve onu takiben gelen İbn Sînâcllı ile kritik bir mücadele evresi şeklinde cereyan eden Fahreddîn er-Râzî, kelâm atomculuğunu savunma noktasında yeni argümanlar inşa etmesinin yanı sıra, İbn Sînâ’nın argümanlarının detaylı bir çürütmesini de yapmıştır.

Anahtar Kelimeler: Atom, Kelâm atomculuğu, İbn Sînâ, Fizik, Atomculuk eleştirileri.

\section{Abstract}

Kalām atomism stood in opposition to the Aristotelian natural philosophy of the falāsifa. In the Physics of the Shifā', Ibn Sinā undertook a detailed Refutation of kalām Atomism through several arguments. These arguments elicited a muted response from al-Ghazālī, whose commitment to kalām was minimal at best. A more forceful response seems to have been offered by al-Shahrastānī but its details remain sketchy due to the lack of surviving sources. Fakhr al-Dīn ar-Rāzī, whose intellectual development went through a phase of commitment to Avicennism and thereby a vigorous endorsement of Ibn Sinā's anti-atomist arguments followed by a phase of a critical engagement with Avicennism, provides a detailed rebuttal to Ibn Sīnā's arguments in addition to constructing novel arguments in defense of kalām atomism.

Keywords: Atom, Kalām atomism, Ibn Sīnā, Physics, Critique of atomism. 


\section{Giriş}

Yunan doğa felsefesindeki atomculuğun kısa ve öz tarihi, "kurucular" Leukippos ve Demokritos tarafindan atomculuğun bir formülasyonunu, Aristoteles tarafindan atomculuğun detaylı bir eleştirisi ve reddini, Aristoteles'in eleştirisi ve reddine cevaben Epikür tarafından Aristoteles sonrası atomculuğun bir sonraki formülasyonunu içermektedir. ${ }^{1}$

Paralel şekilde İslâm doğa felsefesindeki atomculuğun kısa ve öz açıklaması şöyledir: Atomculuğun "kurucuları" erken dönem kelâmcılarıdır ve atomculuk eleştirisi ve reddi İbn Sînâ tarafından yapılmıştır. Özellikle de onun detaylı tartışması Şifâ adlı eserinin Fizik kitabının üçüncü kısmında yer almaktadır. Bu paralelliği bir üst noktaya taşımak için, Yunan atomculuğundaki Epikürcü yeniden formülasyona benzer şekilde, İbn Sînâ sonrası kelâm atomculuğunun yeniden bir formülasyonunun var olup olmadığını sorabiliriz. Bu soruya cevap verebilmek, İbn Sînâ sonrasında Eş'arîler, Mâtürîdîler, Zeydîler ve On iki İmam Şî̂leri (Twelver Shỉiss) tarafından yapılan kelam atomculuk tartışmalarını inceleyerek bir araştırma projesi yapmayı gerektirmektedir. $\mathrm{Bu}$ makale, İbn Sînâ sonrası özellikle Cüveynî, Gazzâlî, Şehristânî ve Fahreddîn er-Râzî gibi bazı Eş‘arî kelâmcıları arasındaki atomculuğun incelenmesi yoluyla böyle bir projenin bir yönüne dikkat çekmektedir.

The Physical Theory of Kalām kitabında kelâm fizik teorisini, ayrık uzay, zaman, hareket teorileri ile boş uzayın kabulüne karşılık gelen atomcu madde teorisinden ibaret şeklinde tanımladım. Mevcut tartışma bu fiziksel teorinin bütün yönlerini incelememektedir. Daha doğrusu o, atomcu madde teorisinin temel sorusu ile sınırlıdır. Ben burada İbn Sînâ'nın Şifâ adlı eserinin Fizik'inin üçüncü kitabında izah edilen atomcu madde teorisinin reddine genel bir bakışla başlıyorum ve ardından bu Eş'arî kelâmcılarının cevaplarını inceliyorum.

\section{1. İbn Sînâ’nın Şifâ Adlı Eserinin Fizik Bölümündeki Atomculuk Tartışması}

Aristoteles, Fizik (5.3) kitabında Demokritos atomculuğunun reddine, fiziksel süreklilik tartışmalarının temel terimleri olan "birleşik", "ayrı", "temaslı", "arasında", "ardışık”, "sürekli" ve "bitişik" gibi terimlerin analiziyle başlamıştır. ${ }^{3}$ Benzer şekilde İbn Sînâ'da Şifầnın Fizik (3.2) bölümünde atomculuk eleştirisine "ardışıklık", "temas”, "girişimlilik", "birliktelik”, "süreklilik", "ara sınır", "beraber olma" ve "ayrı olma" terimlerinin bir analiziyle başlamıştır. İ İbn Sînâ’nın bu terimleri analizi, şaşırtıcı gelmeyecek şekilde ayrık ve bölünemeyenden ziyade sürekli ve bölünebilen gibi büyüklük (magnitude) kavramı üzerine temellendirilmiştir. Aristoteles ve İbn

Bu makalenin daha erken ve daha kısa versiyonu, Avicenna Conference on the Occasion of the Publication of the Healing'de sunuldu. Park City, Utah, Haziran 8-12, 2010. Bu konferansa beni davet eden organizasyona ve yorumları için katılımcı meslektaşlarıma teşekkür ederim.

2 Aşağıda tartışacağım üzere, Şehristânînnin özellikle de hayatının son döneminde Eş‘arîlik'e olan bağlllı̆̆ı İsmâîlîlerle ilişkili görüşlere olan bağlılığını gösteren deliller ışığında sorgulanmıştır. (bk. Toby Mayer'in Keys to the Arcana: Shahrastānī's Esoteric Commentary on the Qur'ān'ın girişi (London: Oxford University Press, 2009), 3-19.

3 D. Bostock, “Aristotle on continuity in Physics VI", Aristotle's Physics: A Collection of Essays, ed. L. Judson (London: Oxford University Press, 1995), 179-212; Pyle, Atomism and its Critics (Bristol: Bloomsbury Publishing Plc, 1995), 2527.

4 İbn Sînâ, The Physics of the Healing, çev. J. McGinnis (Provo: Brigham Young University, 2009), 2/262. Bazı yerlerde McGinnis'in çevirilerinde değişiklikler yaptım. 
Sînâ'nın atomculuk analizlerine bu terimleri tartışmak yoluyla başlama stratejileri, -duyulur cisimlerin gözlemlenen sürekliliği, onların parçalara bölünebilirliği ve bu tür parçalardan oluşumları arasındaki ilişkinin doğası nedir?- şeklindeki temel endişelerini vurgulamaktadır.

İbn Sînâ, tartışmasında duyulur cisimlerin (el-ecsâmü'l-mahșuṣạa) oluşumu hakkında üç görüş zikretmektedir:

ISa. Cisimler, sonlu (mütenâhiye) bölünemeyen parçacıklardan (eczẩ elleẑî lâ yetecezze') bir araya gelerek (te'lifen) oluşur;

ISb. Cisimler, sonsuz parçacıklardan (eczẩ' lâ nihâye lehe) oluşur;

ISc. Cisimler, ya sonlu kendinde bilfiil (actual) parçalardan oluşur ya da kendinde bilfiil parçaya sahip değildir. ${ }^{5}$

İbn Sînâ, ilk görüşün taraftarlarını -"cisimler, atomlarda sona erer diyenleri”'- Demokritos, Proklos ve Epikür gibi Antikler ${ }^{7}$ (el-kudemâ) ile isimlerini zikretmediği modernistler ${ }^{8}$ (el-muḥdeș̂n) olarak tespit etmektedir. Ancak argümanlardan ve delillerden açıtır ki o, modernistler ile bazıları da kendisinin çağdaşları olan atomcu kelâmcılara atıf yapmaktadır. ${ }^{9}$ ìbn Sînâ, onların "delillerini”" (hucec) şöyle zikretmektedir:

ISA1. Cisim, bölünemeyen parçaların bileşiminden (te'lîf) meydana gelir. Bileşim ortadan kaldırıldığı zaman cisim, kendisini oluşturan bölünemeyen parçalarını geride bırakarak yok olur; ${ }^{10}$

ISA2. Bir karıncanın sandalet üzerinden geçişiyle örneklendirilen yarı-mesafeler argümanı (Antikler, Aşil ve kaplumbağa örneğini kullanmıştır). Bu mesafenin geçilmesi için, önce onun yarısı geçilmelidir ve bundan önce de bu yarının yarısı geçilerek başlanabilir vs. Dolayısıyla geçiş ya asla başlamaz ya da bölünmenin bir sınıra ulaşması gerekir. Hareket var olduğundan, bölünme için bir son olmalıdır ve bu nedenle bölünmezler vardır; ${ }^{11}$

ISA3. Şayet bölünme sınırsız olsaydı, bir hardal tanesinin parçaları yeryüzünü tamamen kaplard1, ${ }^{12}$

ISA4. Eğer bölünme sınırsız olsaydı, hardal tanesinin parçaları, muazzam bir dağın parçalarına eşit olurdu, ${ }^{13}$

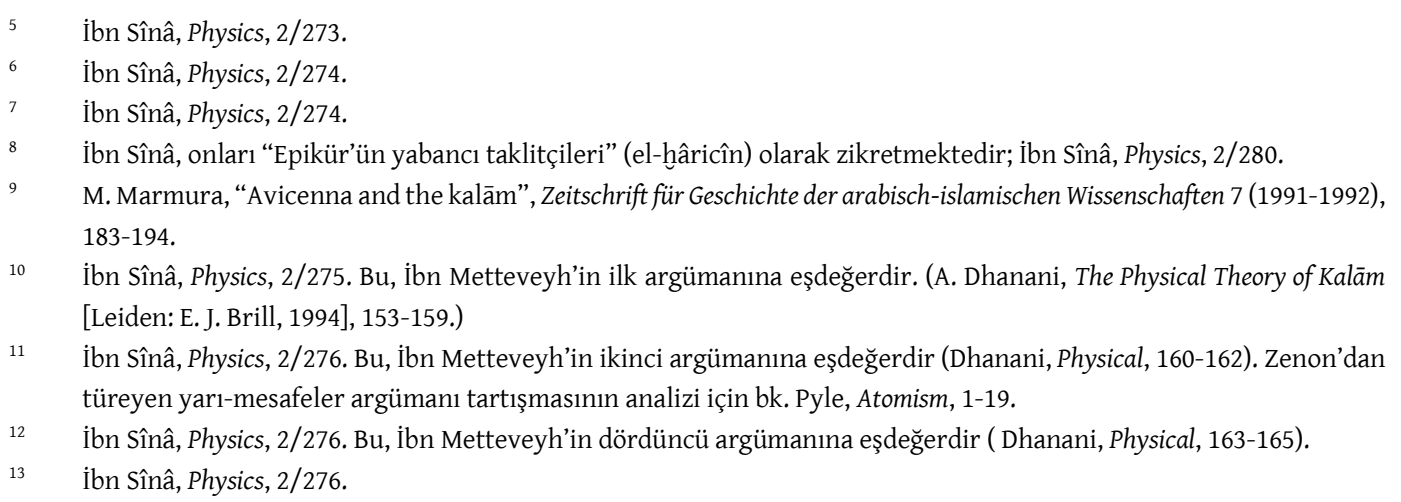


ISA5. Bölünmez kendi başına kâim bir nokta, atoma eşittir; ${ }^{14}$

ISA6. Öklid'e göre küçük bölünmeyen bir açı vardır;

ISA7. Pürüzsüz bir yüzey üzerinde yuvarlanan bir küre, ardışık noktalardan meydana gelen bir çizgi oluşturur. ${ }^{16}$

Cismin oluşumu hakkındaki -sonsuz parçacıkların reel sayısından oluşur- şeklindeki ikinci görüşe dönersek İbn Sînâ, bu görüş taraftarlarını "sıçrama" (țafra) teorisini savunanlar olarak tespit etmektedir. İyi bilindiği üzere, bu teori kelâmcı Nazzâm ve takipçileri tarafından kabul edilmiştir. ${ }^{17}$ İbn Sînâ, birinci görüş taraftarları ile ikinci görüş taraftarları arasındaki tartışmayı, bir değirmen taşı (rahḥã) üzerindeki dairelerin dönme hızındaki farklılıklar üzerinden anlatmaktadır. Tafrayı savunanlar bu değişikliklerin, iki dairenin hareketindeki sıçrama sayısındaki farklılıklardan kaynaklandığını iddia ederken; atomcular hızdaki bu değişikliklerin, dönme sırasında durağanlık ve hareketin dağılmış periyotlarından kaynaklandı̆̆ını iddia etmektedirler. Ayrıca İbn Sînâ tafrayı savunanların, atomcuları dağılmış durağanlık ve hareket teorilerinin, dönme sırasında değirmen taşının parçalanmasını (tefekkük) gerektirdiğini itiraf etmeye nasıl zorladıklarını da anlatmaktadır. ${ }^{18}$

Şifầnın Fizik'indeki üçüncü makalenin dördüncü faslı olan (3.4) "Doğru görüşü saptamak ve yanlış olanı reddetmek” şeklindeki İbn Sînâ'nın bir sonraki bölümü, “[bölünmez] cisim olmayanlardan, cisimler oluşturanları" (mezhebü'l-müellifîn li'l-ecsâm min ġayri'l-ecsâm) reddetmek için ayrılmıştır. İbn Sînâ bu formülasyonla, atomların cisim olmadı̆̆ı ve dolayısıyla bölünemez oldukları şeklindeki atomcu münakaşaya dikkat çekmektedir. O, atomculuğa karşı aşağıdaki argümanları sunmaktadir:

ISB1. Parçalardan bu tür cisimlerin oluşumu, "salt ardışıklık, temas, girişimlilik ya da süreklilik" durumları yoluyla olması gerekir. Ancak bu durumlardan herhangi birinde cisim olmayan parçalardan cisimlerin oluşumu, sürekli bir cisim meydana getirmez. Örnek olarak, art arda üç atomu $(x, y, z)$ al. İki ayrı uçtaki x ve $z$ atomları arasında teması engelleyen ortadaki y atomunun durumu nasıl açılanabilir? Bu $x$ ve $z$ atomlarının her birinin, "kendi başına kaim olmayan" ortadaki y atomu ile "temas halinde" olması gerekir ki bu apaçık ortadadır. Bu nedenle ortadaki atom, zihinsel olarak bölünmektedir. Başka bir deyişle, "ortada olan şey” zihinsel olarak bölünsün diye, $x$ ya da $z$ atomlarından her biri y atomunun farkl1 "kısım", "taraf" ya da "kenarıyla" temas halindedir. ${ }^{19}$

14 İbn Sînâ, Physics, 2/276; Cüveynî, eş-Şâmil fî usûli'd-dîn, ed. A. en-Neşşâr vd. (İskenderiye: Münşeetü'l-Maârif, 1969), 143.

15 İbn Sînâ, Physics, 2/277; Dhanani, Physical, 148-50.

16 İbn Sînâ, Physics, $2 / 277$.

17 İbn Sînâ, Physics, 2/279. bk. R. Sorabji, "Chapter twenty-five: atoms and divisible leaps in Islamic Thought”, Time, Creation, and the Continuum: Theories in Antiquity and the Early Middle Ages içinde (Ithaca: Cornell University Press, 1983), 384-402.

18 İbn Sînâ, Physics, 2/280; Dhanani, Physical, 176-180.

19 İbn Sînâ, Physics, 2/282-284. Jon McGinnis'in atom numaralandırmasını ve şemasını kullandım. Argümanın dayanak noktası, minimal parça ya da atom olmanın, aynı zamanda cisim olmama anlamına geldiğidir. Atomcu kelâmcılar için atomlar, cisim-olmayan olmalarına rağmen minimal büyüklüğe sahiplerdir. Bu nedenle onlar, atomların bir 


\begin{tabular}{|c|c|c|}
\hline$x$ & $y$ & $z$ \\
\hline
\end{tabular}

ISB2. Tek atom katmanından oluşan ve bir tarafı Güneş tarafından aydınlatılan bir plakanın, eş zamanlı olarak diğer tarafının da aydınlatılmış olması gerekir. Çünkü atomlar bölünmez ise, hiç kimse bir tarafı diğer taraftan ayırt edemez. Bu ise mantıksızdır. ${ }^{20}$

ISB3. Atomculuk daire, dik açll üçgen ve benzeri şekiller gibi geometrik nesneleri reddetmeyi gerektiren geometrik zorluklara yol açar. Onar birimlik kenarlara sahip dik açll ikizkenar üçgenin hipotenüsü hesaplanamaz. İbn Sînâ, atomcuların "daire ve dik üçgen konusunda gözün yanıldığını ve bu şekillerin zikzaklı (el-eşkâlü’l-mudarasse) olduklarını” iddia ederek karşıllk verdiklerini bildirmektedir. ${ }^{21}$ Ancak İbn Sînâ, bunun ne yatay ne dikey olmayan köşegenler ve diğer çizgiler ile ilgili daha ileri zorluklara yol açtığını öne sürmektedir. ${ }^{22}$ Bu durum, $A B C$ üçgeninin kelâm atomcularının ayrık hücresel alanında tasvir edildiği şekilde daha net olarak görülmektedir. "Yatay" olan AB ve "dikey" olan AC, "düz" çizgilerdir, ama BC hipotenüsü zikzaklıdır.

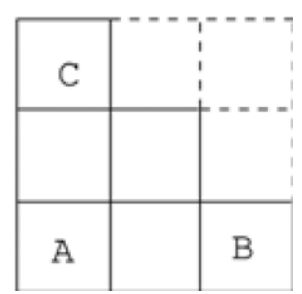

ISB4. $\quad b$ ve $c$ atomlarının üstündeki $a$ atomu, ya $b$ ve $c$ 'nin üzerindedir ya da onlardan herhangi (b ya da $c$ ) birinin üzerindedir.
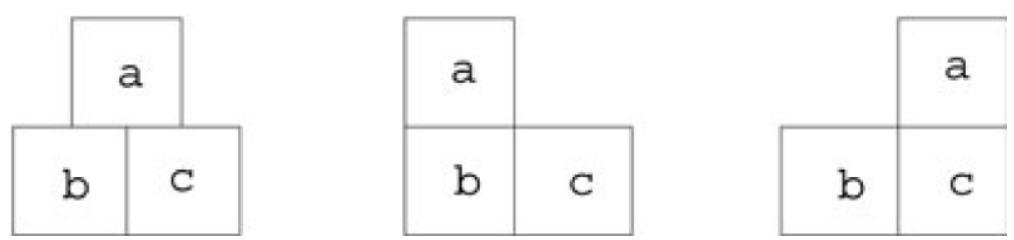

Bu nedenle $a$ atomu, $b$ 'ye ve c'ye aynı anda temas ettiğinde, zihinsel olarak $b$ ve $c$ atomları arasındaki sınır tarafından bölünür. Böylece bir parça b’nin üzerinde ve bir parça c'nin üzerinde kalır. ${ }^{23}$

ISB5. Güneş tarafından aydınlatılan bir gnomon (Güneş saati kadranı), zemin üzerinde bir gölge meydana getirir. Güneş'in gökyüzündeki konumu bir atom mesafesinde hareket ettiği zaman, gölgenin boyu değişmek zorundadır; ancak bu değişim, küçücük ve bir atomdan

araya gelmelerini, onları oluşturan atomların miktarına bağlı büyüklük olan cisimleri meydana getirdiğini iddia ettiler. (Dhanani, Physical, 106-113.)

20 İbn Sînâ, Physics, $2 / 284$

21 İbn Sînâ, Physics, $2 / 286$.

22 İbn Sînâ, Physics, 2/284-291. McGinnis, mudarrase'yı "art arda girintili katmanlar" olarak tercüme etmiştir. Ancak krş. E. Lane, An Arabic-English Lexicon (Beyrut: Mektebetu Lübnan, 1968), 5/255, süt. 5. "Geometrik zorluklar”n kelâmdaki kullanımı için bk. Dhanani, Physical, 172-176.

23 İbn Sînâ, Physics, 2/291-292. İbn Sînâ'nın argümanı, uzayın ve onun yer kaplamasının sürekliliği fikrine dayanmaktadır. Kelâm tartışması için bk. Dhanani, Physical, 126. 
daha az olmalıdır. Bu ise atomun bölünmesini gerektirir. ${ }^{24}$ Benzer şekilde iki kenarı eşit olmayan bir dik açılı üçgenin hipotenüsü çekildiği zaman, daha uzun kenarın bir atom kadar uzanması için, daha kısa kenarın bir atomdan daha az küçülmesi gerekir. ${ }^{25}$

ISB6. Atomcu görüşün gerektirdiği, dönen bir değirmen taşının parçalanmasının saçma sonucu. ${ }^{26}$

ISB7. Yavaşlığın ya da hızlılı̆̆ın, serpiştirilmiş durağanlıkların daha az ya da daha fazla sayısından kaynaklandığı şeklinde ifade edilen hızdaki değişim ile ilgili atomcu muamma. Bu görüşe dayanarak Güneş'in, uçan bir okun ya da dörtnala giden bir atın hızındaki farklılıkları açıklayabilir miyiz? Güneş’in hareketiyle kıyaslandığında, okun ve atın hareketleri binlerce durağanlığa ihtiyaç duyacaktır. ${ }^{27}$

ISB8. Komşu yollarda karşıddan karşıya zıt yönlerde hareket eden iki cisim, hareketleri sırasında birbirlerine hiç karşı olmadan, birbirlerini geçebilirler. ${ }^{28}$ Zıt yönlerde hareket eden iki atom sırası $(a, b, c, d$ ve $e, f, g, h)$ düşünün. $a$ ve $e, b$ ve $f, c$ ve $g, d$ ve $h$ atomları hareketin başlangıcında birbirlerine zıttırlar.

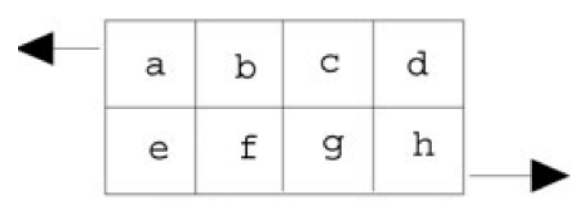

\section{(Hareketin başlangıcı)}

Bir sonraki anda, her iki sıra da bir birim kadar hareket eder:

\begin{tabular}{|l|l|l|l|l|l|}
\hline$a$ & $b$ & $c$ & $d$ & \multicolumn{2}{|c|}{} \\
\hline & e & $f$ & $g$ & $h$ \\
\hline
\end{tabular}

\section{(Bir sonraki anda)}

Bu nedenle $b$ ve $e, c$ ve $f$ ile $d$ ve $g$ atomları hareket boyunca asla birbirlerine karşı olamazlar.

ISB9. Üç tane yan yana sırası ile $a, b, c$ atomlarını ve $a$ ve $c$ 'nin üzerindeki $x$ ve $z$ atomlarını ve bu ikisinin ( $x$ ve $z$ ) arasının, bir atom kadar büyük olan $y$ boşluğuyla ayrıldığını düşün.

24 İbn Sînâ, Physics, 2/293-294. İbn Metteveyh de gnomonu ve onun gölgesini tartışmaktadır (Dhanani, Physical, 129).

25 İbn Sînâ, Physics, 2/295.

26 İbn Sînâ, Physics, 2/295. Kelâm tartışması için bk. Dhanani, Physical, 78-80.

27 İbn Sînâ, Physics, 2/296-297. Kelâm tartışması için bk. Dhanani, Physical, 138-139 ve Dhanani, "Problems in EleventhCentury Kalām Physics", Bulletin of the Royal Institute of Interfaith Studies 4 (2002), 73-96.

28 İbn Sînâ, Physics, 2/298-289. Bunun nedeni, ayrık ya da atomcu uzay teorisinde hareketin anlamının, ayrık uzamsal hücre (ya da uzay-atom) kaynağından hareket eden bir atomun, komşu uzamsal bir hücreye bütünüyle anlık taşınmasıdır. Sonuç olarak, komşu yollarda karşıdan karşıya hareket eden iki atom, birbirlerine hiç karşı olmadan birbirlerini geçebilirler. 


\begin{tabular}{|c|c|c}
\hline$x$ & $y$ & $z$ \\
\hline$a$ & $b$ & $c$ \\
\hline
\end{tabular}

$x$ ve $z$ atomları, $y$ boş alanını işgal etmek için birbirlerine doğru itildiğinde, "vehmimiz" (estimate faculty), onların engel olmaksızın hareket edeceklerini ve x'in yarısı ve z'nin yarısı, artık b'nin üzerinde olan y'nin ortasında buluşacaklarını ileri sürmektedir. Bu durum ise zihinsel olarak bölünen atomları gerektirmektedir. ${ }^{29}$

\section{2. İbn Sînâ'nın Kelâm Atomculuk Eleştirisi ve İbn Metteveyh'in Atomlar ve Arazlar Üzerine Tezi}

İbn Sînâ'nın Şifẩnın Fizik'indeki ve diğer çalışmalarındaki atomculuk eleştirisi, kelâm atomculuk tartışmalarının derin bir anlayışını göstermektedir. İbn Sînâ'nın daha genç çağdaşı olan İbn Metteveyh, atomculuk hakkında en detaylı kelâm kaynaklarımızdan birinin yazarıdır. Atomların ve Arazların Özelliklerine İlişkin Tez'inde (et-Težkire fị ahkâmi'l-cevâhir ve'l-a'râż) İbn Metteveyh, sadece atomculuk için kelâm argümanlarını değil, bunun yanında atomculuğun ortaya çıkardığı "zorlukları" (şübeh), onları zihinsel (akliyyât) olarak küçük parçalara bölmenin zorluklarını, geometrik şekillerle (eşkâl) ilgili şüpheleri ve tafra teorisi tarafından ileri sürülen zorlukları da tartışmaktadır. ${ }^{30}$ Üslup, bakış açısı ve teknik kelimelerdeki farklılıklara rağmen, İbn Metteveyh ve İbn Sînâ'nın tartışmaları arasında çok fazla örtüşme vardır. Burada herhangi bir etki ya da tepki olasılığı var mıdır? Ben öyle olduğunu düşünmüyorum. İbn Metteveyh'in tartışması, günümüze ulaşmayan iki eserde (Muginînnin ilk ciltleri ve Ebü'l-Kâsım el-Belhî’nin Makâlât'ı üzerine şerhi) muhtemelen ayrıntılı olarak detaylandıran hocası Abdülcebbâr'ın öğretisini yansıtmaktadır. İbn Sînâ'nın ikinci eser ile karşılaşmış olabileceğine inanmak için güçlü nedenler bulunmaktadır. ${ }^{31}$ Durum gerçekten böyleyse, o halde İbn Sînâ'nın ve İbn Metteveyh'in açıklamaları arasındaki benzerlikler, ortak bir kaynağa dayandıklarını göstermektedir. İbn Sînâ'nın detaylı kelâm atomculuk tartışmasının, kelâm atomculuğunun taraftarları ve muhaliflerinin argümanlarını ve karşı-argümanlarını muhafaza eden kelâm yazılarına erişiminden kaynaklanmış olması çok muhtemeldir.

\section{3. İbn Sînâ Cüveynînnin Atomculuk Tartışmasını Etkiledi mi?}

29 İbn Sînâ, Physics, 2/299-300. İbn Metteveyh'in bu “zorluk” tartışması için bk. Dhanani, Physical, 128. Benzer bir argüman Sextus Empiricus'ün Against the Physicists kitabında bulunmaktadır (Pyle, Atomism, 33).

30 İbn Metteveyh'in ölüm tarihiyle ilgili kesin bir bilgiye sahip değiliz. Onun, Abdülcebbâr ile çalıştığı apaçık ortada olduğundan, muhtemelen ikincisi (Abdülcebbâr) yaşça daha büyüktür. Abdülcebbâr’n, doksan yaşının biraz üzerinde olduğu 414/1023 ya da 415/1024 tarihinde öldüğünü biliyoruz. Bazı âlimler ise İbn Metteveyh'in ölüm tarihi olarak 468/1075 ya da 469/1076 tarihlerini önermektedir. ( S. Murâd, İbn Metteveyh ve ârầuhu'l-kelâmiyye ve'lfelsefiyye [Kahire: Mektebetü'l-Enclû el-Mısriyye, 1991], 98-99; M. Heemskerk, Suffering in Mu tazilite Theology [Leiden: Brill, 2000], 65.)

31 İbn Sînâ ve Abdülcebbâr arasında "karşılaşma" için bk. A. Dhanani, "Rocks in the Heavens!? The encounter between "Abd al-Jabbar and Ibn Sina”, Before and After Avicenna, ed. D. Reisman (Leiden: Brill, 2003), 127-144. 
Eş‘arî kelâmcı Cüveynî (öl. 478/1085), i̇bn Sînâ’nın bir diğer daha genç yakın çağdaşıdır. Robert Wisnovsky, İbn Sînâ'nın Cüveynî üzerindeki “etkisini”, İbn sînâc1 vâcibü'l-vücûd formülasyonunun ikincisini benimsemesi yoluyla göstermektedir. ${ }^{32}$ Cüveynî̉nin günümüze ulaşan en kapsamlı kelâm atomculuk tartışması, Eş'arî atomculuk bakış açısının yer aldığı eş-şâmil fî usûli'd-dîn adlı eserinde bulunmaktadır. Cüveynî, cismin bölünmesine ilişkin felsefî görüşler ile ilgili şunu ifade etmektedir:

“islâm takipçileri (islâmiyyûn) cisimlerin, bölünmeleri konusunda ferdî (parçalar) ile sonuçlanan bir sınıra ulaştıkları şeklinde ittifak etmişlerdir. Her bir parça ne bir yönü (țaraf) ne de sınırı (hadd) olan bölünmezdir. (Her bir) cüz, ayırt edici özelliğe sahip olmayacak şekilde homojendir. Kendilerini geometriye oldukça fazla kaptırmış olan kimseler, bu görüşe eğilim göstermişlerdir. Ancak onlar "atomu" (cüz'), "nokta" terimiyle belirtmişlerdir. Onlar, noktanın bölünemezliği hususunda eminlerdi. Filozofların çoğunluğu ise, cisimlerin bölünmesinin bir sınırı olmadığı görüşüne yönelmişlerdir. Filozoflar ile ilişkili olan kimseler arasında yer alan Nazzâm da bu görüşe meyletmiştir. Biz öncelikle filozofları reddetmenin yollarını açıklayacağız, ardından Nazzâm’a yöneleceğiz ve dinin esaslarının yıkımına yol açan öğretisini açıklayacağız." ${ }^{33}$

Cüveynî, atomculuğu destekleyen üç argüman sunmaktadır: sonlu bir aralığın, yalnızca sonlu sayıda bölünemez parçalardan oluştuğu için geçilebilir olduğu argümanı (Bu, sonsuz parçalardan oluşan bir aralığı geçmeyi mümkün kılan sıçrama hipotezi şeklindeki Nazzâm'ın karşı-argümanına cevap vermeyi gerektirmektedir.); cisimlerin boyutlarındaki farklllıkların, onları oluşturan atomların sayısından kaynaklandığı argümanı; ve bir cisimdeki bileşimin arazları, zıtlarıyla yani ayrılma arazlarıyla değiştirilmesi durumunda, sonucun ferdî ayrılmış atomlar olacağı argümanı. ${ }^{34}$ İbn Sînâ, Şifầnın Fizik bölümünde bu argümanları zikretmektedir. Ancak Cüveynî’nin, İbn Sînâ'nın atomculuk eleştirisine cevap verdiğini gösteren bir delil bulunmamaktadır. O, İbn Sînâ'nın atomculuk karşıtı argümanlarını ele almamaktadır. Daha doğrusu atomculuk üzerine Cüveynînnin tartışması, İbn Sînâ öncesi Eş'arî söylem ile tutarlıdır.

\section{Gazzâlî̀nin Kelâm Atomculuğuna Karş1 Tutumu}

Birçok çağdaş âlim, Gazzâlî̀yi "Eş'arî teolog" olarak sınıflandırmaktadır. O, Eş‘arîlik'in temel prensiplerine itiraz etmediği halde, Gazzâlî’nin kendisini bir mütekellim olarak niteleyip nitelemediği şüphelidir. Nitekim hayatı boyunca görüşleri bir ilerleme kaydetmesine rağmen, entelektüel hayatının çoğunda kelâm ve tabiilerine çok az itibar etmiştir. ${ }^{35}$

Gazzâlî̀nin atomculuğu benimseyip benimsemediğine dair deliller yetersizdir. İbn Sînâ'nın sisteminin özeti olan, 484/1092 ve 486/1093 tarihleri arasında yazılan Makâsıdül-felâsife'sinde

32 R. Wisnovsky, "One aspect of the Avicennan turn in Sunni Theology", Arabic Sciences and Philosophy 14/1 (Mart 2004), 90. Ancak vâcibü'l-vücûd terimi, kelâm öncüllerine sahip olabilir. Bu terim, Zeydî imâm el-Nâtık-Bilhak Ebû Tâlib Yahyâ b. el-Hüseyin b. Hârûn el-Buthânî (öl. 424/1033) tarafından yazılan Ziyâdât şerhü̈l-usûul'de, öğrencisi Ebü'lKâsım Ahmed b. Mehdî el-Hasanî’nin dirilmesi kısmında görünmektedir. Bu, derinliği belirgin olmayan birçok değişik bölümden oluşan (karma) bir metin olduğu için, vâcibü'l-vücûdun kullanım şeklinin, Kitâbü'l-usûl'ün yazarı İbn Hallâd'a (yk. öl. 330/941) ya da onun şârihi el-Nâtık Bilhak'a ya da ikincisinin (el-Natık Bilhak'ın) öğrencisi Ebü'lKâsım'a atfedilmiş olup olmadığı belirsizdir. (C. Adang vd., Basran Mu 'tazilite Theology: Abū 'Alī Muhammad ibn Khallād's Kitāb al-Usūl and its Reception [Leiden: Brill Academic Publishers, 2011], 4-5, 44, 249).

33 Cüveynî, eş-Şâmil, 143.

34 Cüveynî, eş-Şâmil, 143-147. Bunlar, Basra Mu'tezile'sinin birinci, ikinci ve dördüncü argümanlarına eşdeğerdir.

35 R. Frank, Al-Ghazāli and the Ash'arite School (Durham ve London: Duke University Press, 1994), 1-27, 80-85. 
Gazzâlî, daha sonra Tahâfütü'l-felâsife'de de tekrarladığı bir ifade olan "geometri ve aritmetiğin öncüllerinde mantığa (akla) aykırı hiçbir şey yoktur” demektedir..$^{36} \mathrm{Bu}$ ifade, muhtemelen Gazzâlînnin kelâm atomculuğunun ayrık hücresel alanını ve onunla ilişkili geometrik sorunları reddettiğini göstermektedir. Makâsıd'ın Metafizik'inde cisim hakkında farklı görüşleri tartıştığı kısımda Gazzâlî, cisimlerin atomlardan oluştuğu görüşünü ele almaktadır. O, atomculuğa karşı çoğu İbn Sînâ'nın Necât'indan türeyen altı argüman sunmaktadır. Necât'ta eksik olan bu argümanlardan biri, yukarıda tartışıldığı gibi şifầnın Fizik kitabında yer alan Nazzâm'ın değirmen taşı argümanıdır. ${ }^{37}$ Gazzâlî, bu argümanlardan herhangi birisini reddederek atomculuğu savunmamaktadır. Bunun nedeni olarak Makâsıd'ın, filozofların görüşlerini açıklamak için yazıldığı ve dolayısıyla bir eleştiri olarak yazılmadığı ileri sürülebilir. ${ }^{38}$ Daha doğrusu Gazzâlî, filozofları eleştirisini Tehâfüt'e ayırmıştır.

Tehâfüt'te atomculuk, kurgusal bir muhatabın edebî bir yöntem yoluyla ileri sürdüğü iki yerde küçük bir şekilde ortaya çımaktadır. İlki, insan ruhunda entelektüel bilişlerin (el-ulûmül-aḳliyye) olduğu şeklindeki felsefî görüşe karşı bir itiraz bağlamında ortaya çıkmaktadır. Muhatap şöyle sormaktadır:

“Bilginin bulunduğu yerin (mahal), bölünmeyen bir atom olup yer kapladığını (el-cevherüll-ferd mütehayyiz lâ yenkasim) iddia eden birine, hangi (argümanla) karşı çıkarsınız? Nitekim bunun, kelâmcıların görüşlerinden biri olduğu iyi bilinmektedir." ${ }^{39}$

Gazzâlî, yazar görüşünü öne çıkartarak, kurgusal muhatabı şöyle reddetmektedir:

“Biz, atomla (el-cüz' ellezî lâ yetecezze') ilgili tartışmanın uzunluğundan ve onlar (yani filozoflar), detaylandırılması uzun zaman alacak olan bununla ilgili geometrik argümanlara sahip olduğundan bu makamı sürdürmeyi tercih etmiyoruz. Bunlardan biri, onların "diğer iki atomun ortasındaki bir atomu (cevher) düşünün [...]” ifadesidir. Ancak bu sorunun (şüphe) çözümü, çok uzun zaman alacağından bizim onu irdelememiz gerekmez. O halde diğer tarza geçelim." ${ }^{40}$

Gazzâlî’nin atıfta bulunduğu argüman, İbn Sînâ'nın ISB4'üdür. Gazzâlî, burada bilerek kaçınmasına rağmen, kurgusal muhatabının bu ilk tartışmanın sonunda tekrar araya girmesine izin vermektedir:

"Şayet bir kimse derse ki: Siz bu delilleri, 'bilgi, cisimde yer kaplayan, bölünmeyen bir cevherde bulunmaktadır ki o da atomdur’ (lit. ferdî parça, el-cüz'ül-ferd) şeklinde iddia ederek niçin reddetmiyorsunuz?

36 Gazzâlî, Makâsı 'ü'l-felâsife, ed. M. Kurdī (Kahire: y.y., 1936), 1/3; Gazzâlî, The Incoherence of the Philosophers (Tehâfütü'lFelâsife), çev. M. Marmura (Provo, UT: Brigham Young University Press, 1997), 11.

37 Gazzâlî, Makâsıd, 2/12-16; i̇bn Sînâ, Kitâbü’n-Necât, ed. M. Fahri (Beyrut: Dârü'l-Âfâkı'l-Cedîde, 1985), 139-141.

38 Frank, Makâsıd' ' "tamamen tarafsız bir çalışma" olarak nitelemektedir (Frank, Al-Ghazālì, 93).

39 Gazzâlî, Tehâfüt, 186. Frank (Al-Ghazālī, 58-67), Gazzâlînin, Eş‘arî atomculuğundan kaynaklanan terimleri kullanımını, İhyấ’ daki “akıllı ruh” terimiyle örneklendirmektedir. Mesela, el-cüz'.. elleži lâ yetecezze' ve lâ yenkasim, cüz’ ve cüz-i lâyetecezzâ. Onun görüşüne göre "ancak Gazzâlî tarafından ruh için kullanılan cüz', açık bir şekilde aslında canlı insan bileşiminin ayrık bir elementi olan bölünmez varlık anlamına gelmektedir” (Frank, Al-Ghazälì, 66). Frank'ın görüşünün bir eleştirisi için bk. T. Gianotti, Al-Ghazāli’'s Unspeakable Doctrine of the Soul (Leiden: Brill, 2001), 68-87.

40 Gazzâlî, Tehâfüt, 187. 
Deriz ki: Atom tartışması, geometrik meselelerle ilişkili olduğundan çözümü tartışmayı uzatacaktır. Dahası bu [argüman], atomda kudret ve iradenin bulunmasını da gerektireceği için problemi ortadan kaldirmaz." ${ }^{41}$

Kurgusal bir muhatap kullanmasına ve kaçamak cevaplarına bakıldığında, Gazzâlînnin kelâm atomculuğuna olsa olsa ilgisiz bir bağlllığı var gibi görünmektedir. Ayrıca o açık bir şekilde geometrik argümanların oluşturduğu zorlukları da kabul etmektedir. Gazzâlînnin, İbn Sînâ tarafından Necât'ta zikredilen belirli geometrik argümanları, kendisinin Makâsıd'da zihninde tasvir etmiş olması muhtemeldir. Bana göre, ‘Gazzâlî’nin İbn Sînâ'nın kelâm atomculuğu eleştirisine karşı tepkisi, atomculuğu terk etmek içindi', şeklinde bir sonuca varmak için sağlam bir zemin üzerindeyiz. Ayrıca Gazzâlî’nin kelâmı pek de hevesli olmayan bir şekilde onaylaması, İbn Sînâ'nın atomculuğu reddetmesinin belki de normatif Eş'arî kelâmına duyduğu daha kapsamlı şüpheciliği kadar önemli olmadığını göstermektedir.

\section{5. Şehristânînin Cismin Oluşumu Hakkındaki Görüşü, İbn Sînâ'nın Kelâm Atomculuğu Reddine Bir Cevap Mıdır?}

Kelâm atomculuğunun bir reddi ayrıca İbn Sînâ'nın İşârât'ının Fizik bölümünde de bulunmaktadır. Fahreddîn er-Râzî, bu pasajlara ilişkin yorumunda şöyle demektedir:

Şüphesiz cisim, [tekrarlanan] bölünme yeteneğine sahiptir. Bütün bu bölünmeler, ya mümkündür, bilfiil gerçekleşebilir ya da imkânsızdır. Her iki durumda da onlar ya sonludur ya da sonsuzdur. 0 halde dört ihtimal vardır:

1. Cisim, sonlu sayıda (mütenâhiye) bölünemeyen atomlardan (ecza' lâ tetecezze') oluşur. Bu, bir grup kudemâ tarafından ve müteahhirûn arasında kelâmcıların çoğu tarafından kabul edilen bir görüştür.

2. Cisim, sonsuz sayılda (ǵayri mütenâhiye) bölünemeyen atomlardan oluşur. Bu, Mu’tezilî kelâmcılarından Nazzâm gibi bazı kudemânın kabul etmeye zorlandığı görüştür.

3. Cisim, bilfiil hakiki parçalardan oluşmaz, ancak o, sonlu bölünme yeteneğine sahiptir. Muhammed eş-Şehristânî el-Menâhic ve'l-beyânât adlı kitabında bu görüşü tercih etmiştir. ${ }^{42}$

4. Cisim, bilfiil hakiki parçalardan oluşmaz, ancak o, sonsuz bölünme yeteneğine sahiptir. Bu ise hukemânın çoğunluğu tarafından kabul edilen ve Şeyh'in (yani İbn Sînâ'nın) oluşturmak istediği görüştür. ${ }^{43}$

Birinci, ikinci ve dördüncü görüşler yukarıda tartışılmıştır. Fahreddîn er-Râzî’nin Şehristânî̀ye atfettiği üçüncü görüş ise yenidir. Bu görüş, İbn Sînâcı kelâm atomculuğu eleştirisine bir cevap midır?

Gazzâlî, Tehâfüt, 191.

42 Nasîruddîn et-Tûsî ayrıca şunu ekler: Bu, Fahreddîn er-Râzînnin el-Cevherü'l-ferd başlıklı kitabında söylediği şeydir (ỉbn Sînâ, el-işââât ve't-tenbîhât, ed. S. Dünya [Kahire: Dârü'l-Maârif, 1957-1960], 2/151).

43 İbn Sînâ, el-İşârât, 2/151. Ayrıca bk. Fahreddîn er-Râzî, el-Mebâhisü'l-meşrikiyye, ed. M. el-Bağdâdî (Beyrut: Dârü'lKitâbi'l-Arabi, 1990), 2/15-17. 
Şehristânî’nin entelektüel kariyeri sıra dışıdır. Bağdat'taki Nizâmiyye Medresesi'nde ders vermek için görevlendirilmesinden, Nihâyetü'l-ikdâm ve el-Milel ve'n-Nihal dahil kelâm heresiografik metinlerin yazarlığına kadar erken dönem kariyeri, onun Şâfiî mezhebine ve Eş‘arî kelâmına bağlllığını göstermektedir. Hayatının sonlarına doğru ise İsmâilî görüşleri (eski "Bâtıniyye" öğretisi) kabul etmiştir ve İbn Sînâ'nın metafiziğinin bir eleștirisi olan Musâra'atüll-felâsife'yi kaleme almıştır:

“Aklî ilimlerde en önde gelenin ve felsefede tüm zamanların en bilgininin Ebû Ali el-Hüseyin Abdullah ỉbn Sînâ olduğu noktasında fikir birliği vardır [...] Bir güreş maçında ona meydan okumayı arzu ettim [...] şifầnın Metafizik'inde, Necât'ta, İşârât'ta ve Ta'likkât'ta onun söyledikleri içinde en iyisini ve en sağlamını seçtim. [...]" ${ }^{\prime 4}$

Şehristânî'nin İbn Sînâ’nın eserlerine olan aşinalığı burada açıkça görülmektedir. (O ayrıca kelâm heresiografik eserlerinde, İbn Sînâ'dan ismiyle de bahsetmektedir ${ }^{45}$ ). Musâra'a, belki Gazzâlî’nin daha iyi bilinen Tehâfütü'l-felâsife'si ile karşılaştırılabilir. Şehristânî ayrıca Musâra'a ve diğer kelâm eserlerinde açıkça görüldüğü gibi kelâm atomculuğuna da oldukça aşinaydı. Mesela, Musâra'a'nın ilk sorusunda, "onlar cevherle, bulunduğu mekânı benzerinin işgal etmesinden engelleyen, yer kaplayan cisimleri kasteder" şeklinde not düşerek mevcutların kelâm kategorisinden bahsetmektedir. ${ }^{46}$

Şehristânî’nin atomculuk hakkında eşsiz görüşünü içerdiği gibi, Fahreddîn er-Râzînnin de İşârât atomculuk tartışmalarına ilişkin yorumlarında bahsettiği el-Menâhic ve'l-beyânât, maalesef günümüze ulaşmamıştır. ${ }^{47}$ Bu nedenle Fahreddîn er-Râzî tarafından açılanan Şehristânînnin cisimlerin oluşumu hakkındaki ayırt edici görüşünün, İbn Sînâ’nın atomculuk eleştirisine bir cevap olarak formüle edilmiş olup olmadığını tespit edemiyoruz.

Şehristânîye atfedilen atomculuk üzerine bir diğer eser ise günümüze ulaşmıştır. Bu metin, "atomun varlığının ispatı ile ilgili bir mesele" (mesâil fì isbâti'l-cevheri'l-ferd) başlı̆̆ı taşımaktadır. Nihâyetü'l-ikdâm'in editörü Guillaume, onu basımına ilave olarak yayımlamıştır. Onu, Nihâye'nin Bodleian el yazmasına eklenmiş olarak bulmuştur. İslam atomculuğu-Atomismo e Antiatomismo nel Pensiero Islamico-üzerine çalışmasında bu metinden istifade eden Carmela Baffioni de, bu metni Nihâye'nin Berlin el yazmasına eklenmiş olarak bulduğundan söz etmektedir. Ancak onun, Bibliotheque Nationale (Milli Kütüphane)'deki Nihâye'nin en iyi ve en eski el yazmasında bulunmadığını not etmektedir. ${ }^{48}$ Kelam atomculuğuna karşı birkaç argüman bu metinde bulunmaktadır. Ancak Fahreddîn er-Râzînnin Şehristânî’ye atfettiği cisimlerin oluşumu hakkındaki görüşü destekleyen bir delil yoktur. Bu durum Şehristânînnin iddia edilen bu metnin yazarlığı hakkında daha fazla şüphe uyandırmaktadır ve hatta Baffioni, onun "muhtemelen

44 Şehristânî, Struggling with the Philosopher: a Refutation of Avicenna's Metaphysics. A new Arabic edition and English Translation of Muhammad b. 'Abd al-Karīm b. Ahmad al-Shahrastānī's Kitāb al-Musāra'a, ed. ve çev. W. Madelung - T. Mayer (Londra: Brill, 2001), İngilizce çeviride sayfa 20, Arapça metinde sayfa 3.

${ }_{45}$ bk. Şehristânî̉nin Nihâyetül'-ikdâm'indaki indeks, ed. A. Guillaume (Londra: Oxford University Press, 1934), İngilizce numaralandırmada sayfa 170 .

46 Şehristânî, el-Musāra'a, İngilizce çeviride sayfa 22, Arapça metinde sayfa 7.

47 Bu, büyük olasılıkla Beyhakî tarafından zikredilen el-Menâhic ve'l-âyât ile aynıdır (G. Monnot, Encyclopedia of Islam, New edition, s.v. "al-Shahrastānī”; Beyhakî, Tetimmetu sivanil-hikme, ed. R. el-Acem [Beyrut: y.y., 1994], 120)

48 C. Baffioni, Atomismo et Antiatomismo nel Pensiero islamico (Naples: Istituto Universitario Orientale, 1982), 179. 
düzmece" olduğunu kabullenmektedir. ${ }^{49}$ Bu nedenle İbn Sînâ'nın kelâm atomculuğu eleştirisine karşı Şehristânî’nin cevabını değerlendiremiyoruz.

\section{7. İbn Sînâ’nın Kelâm Atomculuğu Eleștirisine Fahreddîn er-Râzînnin Cevabı}

Fahreddîn er-Râzî, İbn Sînâ'nın eserlerine muhtemelen Gazzâlî ya da Şehristânî'den daha fazla aşinaydı. Râzînin entelektüel biyografi yazarı Muhammed Zerkân, "Uyûnü'l-hikme, İşârât, Kânûn, Şifâ ve Necât" üzerine Râzîye atfedilen şerhleri zikretmektedir. ${ }^{50}$ Râzî, günümüze ulaşan birçok eserinde kelâm atomculuğunu tartışmaktadır. Ancak atomculuk üzerine monografisi -el-Cevherü'lferd- maalesef günümüze ulaşmamıştır. ${ }^{51}$

Carmela Baffioni, çalışmasında Râzî̀yi atomculuk karşıtı ve eleştirmeni olarak nitelemektedir. ${ }^{52}$ Diğer taraftan Muhammed Zerkân ve onun takipçisi Adi Setia ise Râzî̀nin atomculuk taraftarı olduğunu düşünmektedirler. ${ }^{53} \mathrm{Bu}$ taban tabana zit sonuçlar, bu metinlerden hangisinin Râzînin "gerçek" görüşünü yansıttığına dair değerlendirmelerindeki farklılıkların yanı sıra bu yazarlar tarafından incelenen farklı metinlerden de kaynaklanmaktadır.

Zerkân, entelektüel biyografisinde Râzînnin eserlerini kelâm, felsefe ve bu ikisinin sentezi ile diğerlerini ihtiva eden çeşitli disiplinlere ait olarak sınıflandırmaktadır. ${ }^{54}$ Zerkân'a göre Râzînnin eserlerinde yer alan görünüşte çelişkili görüşler, bu örneğin, entelektüel kariyerinin en erken döneminde atomculuğu desteklemesi, ardından atomculuğu reddetmesi, sonrasında atomculuğa ve reddine ilişkin kararsız bir görüş benimsemesi ve nihayetinde atomculuğu desteklediği eski görüşüne geri dönmesi, gelişimsel bir bakış açısı içinde açıklanmalıdır. Zerkân, Râzînnin erken dönem atomculuk kabulüne örnek olarak, onun Eş‘arînin görüşlerine bağlı olduğu, "entelektüel hayatının başlangııında” yazıldığına inandığı Râzînin el-Işâââ fî ilmi'l-kelâm'ına işaret etmektedir. "Doğru görüş, şeyhimiz Ebû Hasan el-Eşsarî (Allah ondan razı olsun) tarafından kabul edilmiş olandır" şeklindeki ifadesinde bu açıkça görülmektedir. ${ }^{55}$ Zerkân, Râzî’nin atomculuğu reddettiği

49 Baffioni, Atomismo et Antiatomismo, 179. Ancak Beyhâkî tarafından Şehristânînin eserlerinin eksik listesinde ondan açıça bahsedilmemesine rağmen, Monnot onu Şehristânî’nin eserlerinden biri olarak zikretmektedir (Monnot, "alShahrastānī" ; Beyhâkî, Tetimmet, 119-121).

50 Zerkân, Fahreddîn er-Râzî ve ârâ'uhu'l-kelâmiyye ve'l-felsefiyye (Kahire: Dârü'l-Fikr, 1963), 80, 82, 106, 124. Zerkân, Kânûn şerhinin, muhtemelen sadece Külliyât kısmının üzerine olduğunu ve Şifâ üzerine şerhin ise muhtemelen sadece Metafizik kısmının üzerine olduğunu belirtmektedir. Ayrıca o, Şifâ ve Necât üzerine şerhlerin aslına uygunluğu ile ilgili şüpheleri de dile getirmektedir.

51 Zerkân, Fahreddîn er-Râzî, 70; Baffioni, Atomismo, 212. Bu metinden ayrıca Nasîruddîn et-Tûsî tarafından Isşarât şerhinde de bahsedilmektedir (İbn Sînâ, Işârât, 2/151); Aslında Fahreddîn er-Râzî’nin günümüze ulaşmış el-Cevherü’lferd isimli risalesi bulunmaktadır. Bu risalenin tahkiki ve değerlendirmesi için bk. Eşref Altaş, "Fahreddîn er-Râzînnin el-Cevherü'l-ferd Adlı Risalesinin Tahkiki ve Tahlili”, Nazariyat İslam Felsefe ve Bilim Araştırmaları Dergisi 2/3 (Ekim 2015), 75-170. (Ç.N)

52 Baffioni, Atomismo, 211-275.

53 Zerkân, Fahreddîn er-Râzî, 419-438; A. Setia, "Atomism versus hylomorphism in the kalam of al-Fakhr al-Din al-Razi: a preliminary survey of the Matalib al-'Aliyyah”, Islam and Science 4/2 (2006), 113-140.

54 Zerkân, Fahreddîn er-Râzî, 67-98.

55 Zerkân, Fahreddîn er-Râzî, 69. İşârâ metni yakın zamanda yayımlanmıştır. (Fahreddîn er-Râzî, el-İşârâ fì ilmi'l-kelâm, ed. H. Muhammed [Kahire: Mektebetü'l-Ezheriyye li't-Türas, 2009]). Zerkân, Râzînin Eş‘arî̀ye itaati hususunda değerlendirmesinde haklı olsa da, İşârầda başlı başına bir atomculuk tartışması bulunmamaktadır. Daha doğrusu, onun konusu öncelikli olarak teolojiktir, yani Tanrı, O'nun sıfatları, gayb [prophecy], vahiy, diriliş, vs. dir. Râzî, kelâmî bağlamda atomu, felsefî bağlamda ise cismi ifade eden, cevher terimini kullanmaktadır. Ancak Râzî cevheri, her ikisi 
sonraki dönem için, el-Mebâhisü'l-meşrikıyye'sine ve İbn Sînâ'nın İşârât'ı üzerine yazdığı şerhine işaret etmektedir. Zerkân, bunların her ikisini de, Râzî kırk yaşına gelmeden, hicri 582/1186'dan önce yazılan felsefî eserleri olarak sınıflandırmaktadır. ${ }^{56}$ Ancak Zerkân, "bu iki eserde bulunanların Râzî’nin gerçek görüşü olduğunu iddia edemeyiz" demektedir. ${ }^{57} \mathrm{O}$, bu eserlerde bulunan atom karşıtı argümanların, Râzînnin entelektüel kariyerinin bu aşamasında Aristotelesçilik ve İbn Sînâcılık ile derin etkileşimini gösterdiğini iddia etmektedir. Zerkân, felsefî bir eser olarak sınıflandırdığı el-Mülahhas fi'l-hikme ve'l-mantık'ta ve kelâmî bir eser olarak sınıflandırdığı Nihâyetü'l-ukūl'da, Râzînnin atomculuğu ne desteklediği ne de reddettiği şeklinde kararsız bir tutum sergilemiş olduğu entelektüel kariyerinin bir sonraki aşamasını gördüğümüzü söylemektedir. Râzî, herhangi birisini savunmaksızın her iki görüş için de argümanları zikretmektedir. Râzî bu kararsızlığı, kararsız olan ilk kişinin kendisi olmadığını; Cüveynî ve Mu'tezilî Ebü'l-Hüseyin el-Basrî'nin bu konuda kendisinden önce geldiklerini iddia ederek savunmaktadır. ${ }^{58}$ Zerkân, Râzî’nin atomculuk hakkındaki nihai görüşünü, son önemli eserlerinden biri olan el-Metâlibü'l-âliye'de ifade ettiğini düşünmektedir. Zerkân'a göre kelâm ve felsefe arasında bir sentez olan bu eserde Râzî erken dönem atomculuk kabulüne tekrar dönmektedir. ${ }^{59}$

Adi Setia, 2005 doktora tezi ve ondan kaynaklanan yayınlarında, Zerkân'ın gelişimsel tezini, kronolojisini ve sonucunu kabul etmektedir. Setia, Râzînnin atomculuğu onayladığı görüş olan "nihai" teorisine odaklanmaktadır. ${ }^{60}$

Diğer taraftan Râzînnin atomculuk karşıtı olduğunu düşünen Carmela Baffioni ayrıca gelişimden de bahsetmektedir. O, el-Mebâhisü'l-meşrikıyye'nin Râzînnin "gençliği sırasında" kaleme aldığı, daha sonra diğer teolojik eserlerde kısaltacağı argümanların olduğu bir eser olarak düşünmektedir. ${ }^{61}$ Bu nedenle Baffioni, atomculuğa karşı Mebâhis argümanları için kayda değer bir alan ayırmaktadır. Ayrıca Baffioni, "olgunluk dönemi eserlerinden biri" olan, yani atomculuğa karşı argümanların ardından atomculuğu kabul ettiği argümanların olduğu el-Erbaîn fi usûli'd-dîn'i de tartışmaktadır. ${ }^{62}$

de atomu ifade eden el-cüz' elleži lâ yetecezze' ya da el-cevherü'l-ferd ile açık bir şekilde bir tutmamaktadır. Mesela, bilginin (ilim) derinlemesine düşünme (nazar) yoluyla nasıl ortaya çıtıı̆̆ tartışmasında Râzî "bazıları 'nazar, bilgiyi meydana getirir (yüvellid)' der; diğerleri 'nazar, bilgiyi gerektirir (yüveccibü)' der; ve yine başkaları 'o, cevher ve arazların ayrılmaz niteliklerini (yülâzimü mülâzime) gerektirir' der” şeklinde ifade etmektedir. (Fahreddîn er-Râzî, el-işârâ, 45). Ayrıca Râzî, kelâm seleflerinin daha ziyade atomu (cevher ya da cüz') kullandığı yerde, cismi kullanmayı tercih etmektedir. Mesela, "cisimlerin varlı̆̆ zamansal bir başlangıca sahiptir" bölümünde o, "cisimler zamansal oluşumlardan (havâdis) yoksun değildir” demektedir. Zamansal oluşumlardan yoksun olmayan şey ise geçici (hâadis) olmalıdır. Bu nedenle cisimler, zamansal olarak yaratılırlar" (a.mlf., el-Işâââ, 53) ya da "cisimler homojendir (el-ecsâm küllühü mutemâsile)" (a.mlf., el-işârâ, 61).

56 Zerkân, Fahreddîn er-Râzî, 80-81, 84-85. Mebâhis'in editörü Muhammed el-Bağdâdî, Mebâhis ve Mülahhas' ın da hicri 582'den önce yazıldığını eklemektedir (Fahreddîn er-Râzî, el-Mebâhis, 1/72).

57 Zerkân, Fahreddîn er-Râzî, 426.

58 Zerkân, Fahreddîn er-Râzî, 426. Nihâyetü'l-ukūl'dan alınt1, Dâru'l-Kütübi'l-Mısriyye yazma eserinde 2/144, Tawhīd 748.

59 Zerkân, Fahreddîn er-Râzî, 92-96, 427. Zerkân, kelâm ve felsefe arasında sentez kategorisindeki bir diğer eserin elMuhassalü efkâri'l-mütekaddimîn ve'l-müteahhirîn olduğunu düşünmektedir.

60 Setia, The pyhsical Theory of Fakhr al-Dīn, al-Rāzī (Malezya: International Islamic University Malaysia, Doktora Tezi, 2005) ve "Atomism versus hylomorphism."

61 Baffioni, Atomismo, 211.

62 Baffioni, Atomismo, 260. Zerkân'a göre (Fahreddîn er-Râzî, 67), Râzî Erbaîn'i oğlu Muhammed için yazmıştır. Zerkân, onun kaleme alındığı tarih hakkında bir bilgi verememektedir, ancak metin arası atıfların analizi, onun nispeten daha sonraki bir eser olduğu izlenimini vermektedir. 
Baffioni eserini kaleme aldığı zaman, Metâlib metninin henüz yayımlanmamış olması gibi iyi bir nedenle el-Metâlibü'l-âliye'ye başvurmamıştır. ${ }^{63}$

Fahreddîn er-Râzînnin atomculuğu üzerine yapılan bu modern çalışmalar, burada tartışılan metinler için bir bağlam sağlamaktadır. Fahreddîn er-Râzînnin İbn Sînâ'nın atomculuk reddiyle etkileşimini göstermek amacıyla, atomculuk aleyhindeki Mebâhis argümanlarını inceleyeceğim. Ardından Metâlib'deki atomculuk tartışmasını inceleyeceğim. Son olarak Erbaîn'deki tartışmayı kısaca değerlendireceğim.

Râzî Mebâhis'te, atomculuğu cevhere ilişkin kısımda tartışmaktadır. Râzî, "cismin” tanımlarını ve cisimlerin bölünebilirliği hakkındaki farklı görüşleri tartışarak başlamaktadır. Ardından üçüncü "bölümde" (fașl) "atomculuk aleyhindeki delillere" (el-edille 'ale buțlâni'l-cüz' elležî lâ yetecezze') geçmektedir. Râzînnin Mebâhis'te atomculuğu kabul ettiğine dair herhangi bir argüman tartışmadığını fark edebiliriz. Atomculuğa karşı yirmi “kesin delil” (berâhin) şunlardır:

RMb1. Bu argüman, ISB1'e karşılık gelmektedir. İbn Sînâ'nın Şifâ adlı eserinin Fizik kitabındaki ilk argümanı, ardışıklık, bitişiklik, girişimlilik ya da süreklilik yoluyla bölünemezlerden oluşan sürekli cisimlerin oluşumunun analizine dayanmaktadır. Râzînin tartışması ise daha detaylıdır, üç itiraz (şükûk) ortaya atmaktadır ve onlara cevaplar vermektedir. Onun değerlendirmesine göre, bu güçlü bir argüman (leyse fí gâayeti'l-metâne) değildir. ${ }^{64}$

RMb2. Bu argüman, iki uca yerleştirilen ve daha sonra ortadaki boş alanı işgal etmek için hareket eden iki atomun üzerinde bulunduğu üç atom sırasını gösteren ISB9'a karşılık gelmektedir. ${ }^{65}$

RMb3. Bu argüman, birbirlerine karşı olmaksızın birbirlerini geçen iki komşu cisim hakkındaki ISB8'e karşılık gelmektedir. ${ }^{66}$

RMb4. Bu argüman, hızdaki değişimlerin hareket ve sükûnun iç içe geçmesiyle oluşan farklılıklardan kaynaklandığı şeklindeki atomcu açıklamanın reddine dayanan ISB7'ye karşıllk gelmektedir. Râzî şunu ileri sürmektedir:

“Şayet hareketin yavaşlığı, dağılmış durağanlıkların sonucu değilse, o halde atomculuk geçersiz olur. Öncül, hareketle ilgili bölümde tartışllan şeyle uyum içinde doğru olduğu için, sonuç da doğru olmalıdır. Koşullu önerme için dayanak şu şekildedir: Eğer atom var olsaydı ve biz bir mesafeyi yüksek hızda geçseydik, bu aralıktaki atomlarının tümünün içinden de geçmiş olurduk. Eğer bir

63 Baffioni, Muhammed Ebû Zekeriyyâ er-Râzînnin atomculuğunu tartıştığı sırada Metâlib'e iki yerde atıfta bulunmaktadır. Her iki atıf da, Paul Kraus'un Râzî’nin bu daha erken döneme ait görüşleriyle ilişkili fragmanlarının koleksiyonuna dayanmaktadır. Bu durumda fragmanlar Fahreddîn er-Râzînin Metâlib'inden alınmaktadır (Baffioni, Atomismo, 130-133).

64 Fahreddîn er-Râzî, el-Mebâhis, 2/19-22.

65 Fahreddîn er-Râzî, el-Mebâhis, 2/23.

66 Fahreddîn er-Râzî, el-Mebâhis, 2/23. Ancak Râzînnin yapılandırması farklıdır. İbn Sînâ gibi, onun da dört atom sırası $(a, b, c, d)$ vardır. Daha sonra sıranın en sağındaki $(d)$ atomun üzerinde $(y)$ atomu ve sıranın en solundaki $(a)$ atomun altında $(z)$ atomu vardır. Şimdi $y$ ve $z$, sıradaki atomların uçlarına doğru hareket etmeye başlarlar. Onlar hareketleri esnasında, sıradaki atomların her birine karşı olmalarına rağmen, asla birbirlerine karşı olmayacaklardır. 
atomun yüksek hızda geçişi belirli bir zaman alıyorsa, o halde aynı zaman için daha yavaş hızda geçiş, bir atomdan daha az bir geçişi gerektirir. Dolayısıyla atom bölünür!" ${ }^{67}$

RMb5. $\quad b$ atomundan $c$ atomuna hareket eden bir $a$ atomu, ya hareketin başlangıcında $b$ ile temasta iken hareket ediyordur ki bu ise imkânsızdır ya da hareketin sonunda $c$ atomu ile temas halindeyken hareket ediyordur ki bu da aynı şekilde imkânsız olur.
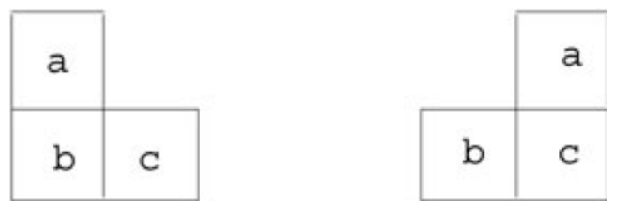

Dolayısıyla $a$ atomu, $b$ ve $c$ atomları arasındayken hareket ediyor olmalıdır. $\mathrm{Bu}$ ise atomun bölünmesini gerektirmektedir! ${ }^{68} \mathrm{Bu}$, İbn Sînâ’nın Şifâ adlı eserinin Fizik kısmındaki bir argümana karşılık gelmemektedir.

RMb6. Bu argüman, atomlardan oluşan tek bir tabakanın Güneş tarafından bir yönünün aydınlatılmasıyla ilgili olan ISB2'ye karşılık gelmektedir. ${ }^{69}$

RMb7. Bu argüman, atomun sonlu olduğunu ve her sonlu cismin bir şekle sahip olduğunu, her şekle sahip olanın ise bir kenar tarafından sınırlandırıldığını iddia etmektedir. o halde atom bir kenar tarafından sınırlandırılırsa, bu kenar sadece bir küre olabilir. Küreler bir araya getirildiği zaman, onların birleşimi tam bir cisim meydana getirmez, ama bir atomdan daha küçük olan boyutta boşluklar içerirler. ${ }^{70}$ Bu, Şifâ’nın Fizik kısmında bir argümana karşılık gelmemektedir.

RMb8. Bu argüman, toprağa yerleştirilen bir gnomonun gölgesi hakkında olan ISB5'e karşıllk gelmektedir.

RMb9. Bu argüman, ISB6'daki parçalanan değirmen taşı saçmalığına karşılık gelmektedir. Ancak Râzî, değirmen taşı yerine topaç (düvvâme) kelimesini kullanmaktadır. ${ }^{71}$

RMb10. Üç bölmeli bir pusulanın (fircâr) dış bölmelerinden biri, bir atom kadar indirildiği zaman, orta bölmenin bir atomdan daha az indirilmiş olması gerekir. ${ }^{72} \mathrm{Bu}$, Şifầnın Fizik bölümünde bir argümana karş1lı gelmemektedir.

RMb11. RMb11-RMb17. Bu argümanlar, daireler, doğru açılar, köşegenler vb. ile ilgili geometrik zorluklar hakkındaki ISB3'e karşılık gelmektedir. ${ }^{73}$

RMb18. Üç sıralı j, b, $a$ atomlarından $a$ atomu üzerine bir $z$ atomu yerleştirilir.

67 Fahreddîn er-Râzî, el-Mebâhis, 2/23. Daha erken kapsamlı hareket tartışması 1/593-681'dedir.

68 Fahreddîn er-Râzî, el-Mebâhis, 2/23-24. Bu nedenle Themistius'un Epikürcü atomculuk hakkındaki görüşü, kimsenin bir atomun hareket halinde olduğunu söyleyemeyeceği, yalnızca onun "hareket etmiş olduğunu" söyleyebileceği şeklindedir (D. Furley, Two Studies in the Greek Atomists [Princeton: Princeton University Press, 1967], 113-114).

69 Fahreddîn er-Râzî, el-Mebâhis, 2/24.

70 Fahreddîn er-Râzî, el-Mebâhis, 2/24.

71 Fahreddîn er-Râzî, el-Mebâhis, 2/25-26.

72 Fahreddîn er-Râzî, el-Mebâhis, 2/26.

73 Fahreddîn er-Râzî, el-Mebâhis, 2/26-29. 


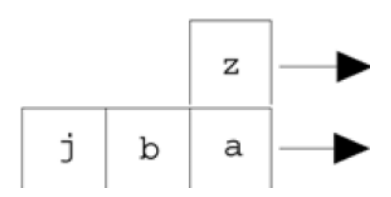

$a$ atomu yeni bir alana hareket etsin diye, atom sırası bir boşluk sağa hareket eder. Şimdi $b, a^{\prime}$ nın önceden olduğu yerde; $j$ ise $b$ 'nin daha önce olduğu yerdedir. Aynı zamanda $z$ atomu da $a$ 'dan aynı yönde uzaklaşır. $z$ hareketinden sonra ya a'nın üzerindedir, ancak bu mümkün değildir, çünkü o halde $z$, a'dan uzaklaşmazdı ve bu varsaydığımız şeydir. Ya da $z$, a'nın yeni mekânı üzerindeki yerin bitişiğinde bir yerdedir. Ancak bu z'nin, $a$ 'dan daha hızlı hareket etmesini gerektirir. Çünkü bu durumda $a$ bir alan kapladığ sürede, o iki atomik alan kaplardı. Dahası bu, $z$ bir atom kadar geçtiği zaman, $a^{\prime}$ nın yarım atom kadar geçmesini gerektirir. ${ }^{74}$ Yetersiz bir şekilde formüle edilen bu argüman, Şifầnın Fizik bölümünde bulunmamaktadır.

RMb19. Bu, İbn Metteveyh tarafından açıklanan Nazzâm'ın kuyu ve kova argümanıdır. ${ }^{75} \quad$ Yüz birim derinliğindeki bir kuyunun, orta kısmında yani elli birim derinliğin olduğu yerde ahşap bir kiriş vardır. Halatın elli birim uzunluğundaki bir ucu (RA) kirişe

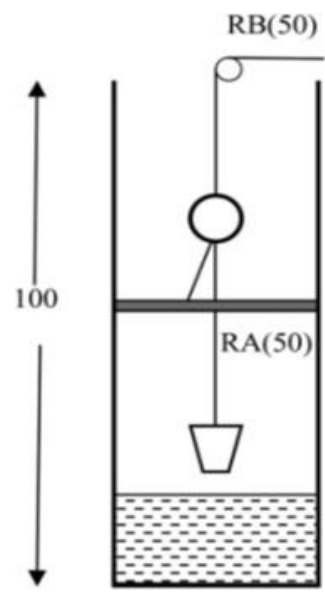
tutturulur. Sonrasında bir halkanın içinden geçirilir ve diğer ucu kovaya tutturulur. Elli birim uzunluğundaki bir diğer halat $(R B)$ da halkaya tutturulur. $R B$ halatı elli birim uzunlukta yukarı çekildiğinde, başlangıçta kuyunun dibinde olan kova, kuyunun tepesine ulaşır. Dolayısıyla RB elli birim geçerken, kova yüz birim geçer. Râzî bunun, bölünemez olduğu varsayılan zaman ya da hareketin bölünebilirliğini gerektirdiği sonucuna varmaktadır. ${ }^{76}$ Bunun aksine İbn Metteveyh'in sonucu (ya da muhtemelen Nazzâm'in sonucunu açıklamaktadır?) kova tarafından geçilen her iki atom için, halatın bir atom geçtiği ya da Nazzâm'ın formülasyonunda kovanın bir birim geçtiği ve halat tarafından geçilen her birim için, bir birim sıçradığı şeklindedir. Şifầnın Fizik kısmında buna karşılık gelen bir argüman yoktur.

RMb20. Bu argüman, gnomon gölgesi argümanına bir çerçeve oluştururken, bir uzunluğu tek sayılı atomlara bölmekle ilişkili bir probleme dayanmaktadır. ${ }^{77}$ Şifầnın Fizik kısmında buna karşılık gelen bir argüman yoktur.

Râzînnin Mebâhis'teki atomculuğa karşı yirmi argümanının altısı hariç tümünün İbn Sînâ’nın Şifâ adlı eserinin Fizik bölümündeki argümanlarından türediğini görebiliyoruz (ISB1, ISB2, ISB3, ISB5, ISB6, ISB7, ISB8, ISB9).

Şimdi onun entelektüel kariyerinin sonraki kısmina geçelim. Fahreddîn er-Râzî, Metâlibü’lâliye'sini, "Yunan dilinde teoloji (uthulujiya) olarak isimlendirilen, metafiziğe ilişkin kitabımız (el-

74 Fahreddîn er-Râzî, el-Mebâhis, 2/29.

75 Dhanani, Physical, 180-181.

76 Fahreddîn er-Râzî, el-Mebâhis, 2/30.

77 Fahreddîn er-Râzî, el-Mebâhis, 2/30. 
ilmü'l-ilâhî)" olarak nitelemektedir. ${ }^{78}$ Bu eserin temel yapısı esas olarak teolojiktir (Tanrı, sıfatlar, gayb, özgür irade, vs.). Ancak onun dokuz bölümünden, beşinci bölümü zaman ve mekân konularına ayrılmışken, altıncı bölümü madde (heyûla) konusuna ayrılmıştır. Altıncı bölümdeki geniş çaplı atomculuk tartışması, Beyrut baskısında yüz kırk sekiz sayfa yer kaplar ve bu nedenle o, Râzînnin bu konuyla ilgili en kapsamlı tartışmasıdır. ${ }^{79}$

Râzî, atomculuğu destekleyen argümanları (edille); hareket ve zamana, geometrinin prensiplerine, cisimlerin büyüklüğünün sonluluğuna ve diğer delillere dayanan argümanlar şeklinde siniflandırmaktadır.

Hareket ve zamana dayalı argümanlar kategorisi, zaman, hareket ve uzay/mesafenin birbirleriyle alakalı (umûr șelâse mütețâbika) olduğu sözüyle başlamaktadır. Dolayısıyla bir şey bölünmezlerden oluşuyorsa, o halde tamamı bu şekilde oluşmalıdır. Benzer şekilde bir şey sürekli bölünüyorsa, o halde tamamı sürekli bölünebilir olmalıdır ki bu ise filozofların görüşüdür. ${ }^{80}$ Böylece Râzî, hareketin ya da zamanın bölünmezlerden oluştuğunu ve dolayısıyla uzayın/mesafenin (ve maddenin!!) de bölünmezlerden oluşması gerektiğini göstermeyi amaçlamaktadır.

Râzî, birbirine eklenen mekânlarda birbirini izleyen varlık olarak (ḥuṣûlât müteâkikibe fí ahyâzz mütelâşıka) tanımladığı harekete dayanan atomculuğu desteklemek için altı argüman takdim etmektedir. Şimdi ilk argümanı (hucce) gözden geçirelim. Râzî, bir cisim tamamen hareket halindeyse, onun şu anda (el-hâli'l-hâdır) da hareket ediyor olması gerektiğini iddia etmektedir. Ayrıca şu andaki hareket bölünmez olmalıdır. Çünkü bölünebilir olsaydı, bir parçası diğerinden önce gelirdi. Ancak bu imkânsızdır. Çünkü o zaman hareketin ilk kısmı, önceki kısma da sahip olduğu için bölünebilir olurdu ve böylece sonsuza kadar giderdi. Dolayısıyla şu andaki hareket bölünebilir olsaydı, o bir bütün olarak (bitt-tamâmih) bu anda asla var olamazdı. Öyleyse bir bütün olarak var olan şu andaki hareket bölünmez olmalıdır. Şu andaki bu bölünmez hareket sona erdiği zaman, bir sonraki var olmaya başlar ve bu da bölünemez. $\mathrm{O}$ da sona erdiğinde, bir sonraki var olmaya başlar ve bir bölünmez hareketin ardından diğerinin gelmesi şeklinde böylece devam eder. $^{81}$

Râzî, atomculuk için harekete dayalı bu argümanlardan sonra zamana dayalı dört argümana geçmektedir. 0 zamanın, her biri bölünmez olan, art arda gelen anlardan (el-ânâtü'l-mütetâliye) oluştuğunu göstermeyi amaçlamaktadır. Onun üçüncü argümanını inceleyelim: Râzî, zamanın ya "sürekli bir varlık gibi" (kemâ muttasll), ya da "süreksiz bir varlık gibi" (kemâ munfaṣl) olduğunu iddia etmektedir. Birincisi, geçmiş ve gelecek var olmadığı için yanlıştır. Râzî ‘şimdinin', geçmişin sonu ve geleceğin başlangıcı olduğundan dolayı, onun zamanın bir parçası olmadığı şeklindeki felsefî iddiayı reddetmektedir. 0 , bu görüşün var olmayan bir gelecek ile var olmayan bir geçmişin sürekliliğini ima ettiği için yanlış olduğunu ileri sürmektedir. Bundan şu sonuç çıkmaktadır:

\footnotetext{
Fahreddîn er-Râzî, el-Mebâhis, 2/33.

Râzî, Metâlib’te atomculuk için Cevher-i ferd başlıklı bir monografi kaleme aldığını not etmektedir (el-Metâlib, 6/32). Bu metin günümüze ulaşmamıştır (Zerkân, Fahreddîn er-Râzî, 70).

80 Fahreddîn er-Râzî, el-Metâlib, 6/29-30, 45-46. İbn Sînâ, Şifâ’nın Fizik kısmındaki 3.6 kısmında uzay, zaman ve hareketin karşılıklı ilişkisini tartışmaktadır (íbn Sînâ, Physics, 2/311-19). Tabi ki Aristoteles tarafından bu karşılıklı ilişki daha erken ele alınmıştır.

81 Fahreddîn er-Râzî, el-Metâlib, 6/30-34.
} 
zaman ayrık olmalıdır ve müteakip birimlerden, yani ardışık anlardan oluşmalıdır. ${ }^{82}$ Dolayısıyla zaman bölünmez parçalardan oluşmaktadır ve bu, madde, mekân ve hareketin de bölünmez parçalardan oluşmasını gerektirmektedir.

Râzînnin argümanlarının ikinci kategorisi, geometrinin prensiplerine dayanmaktadır. Burada onun amac1, atomu kabul etmeyi gerektiren bölünmezlerin (bir kürenin düz bir yüzeyle temas halinde olduğunda gibi) varlığını göstermektir. ${ }^{83}$ Râzî, dört "kesin kanıtın" (burhân) üçüncüsünde şunu söylemektedir:

“Nokta, konuma sahip olan bölünmez bir varlıktır (en-nukța șey’ün žü vad in lâ yenkasim).” Durum böyle olduğunda, atomu destekleyen doktrin zorunlu olarak ardından gelir. ${ }^{84}$

Râzînin argümanlarının üçüncü kategorisi, cisimlerin büyüklüğünün sonluluğuna dayanmaktadır. Bu argümanlar, sonlu büyüklükteki bir cismin, sonsuz olarak bölünebildiği takdirde, onun bilfiil sonsuz parçalardan oluşması gerektiği önermesi üzerine temellendirilmektedir. Râzî, sonuç yanlış olduğu için, öncülün de yanlış olması gerektiğini iddia etmektedir..$^{85} \mathrm{O}$, "sonsuz bölünebilme" ile filozofların potansiyel bölünmeyi, yani her bölünmeden sonra daha ileri bir bölünmenin daima mümkün olduğunu kastettikleri felsefî itiraza dikkat çekmektedir. Bu demektir ki, sonsuz bölünmenin imkânını savunmak, sonsuz bölünmenin gerçekleşmesini gerektirmemektedir. Ancak Râzî, sonsuz bölünmelerin her birinin, bölünmeleri için hiçbir engel olmadığından gerçekleşebilir olduğunu iddia etmektedir. Dolayısıyla aksi, yani cismi oluşturmak için bu sonsuz bölünmelerin birleşiminin de gerçekleşebilir olması gerektiği, bilfiil sonsuz parçalardan bir cismin oluşumunun mümkün olduğu anlamına gelmektedir. ${ }^{86}$

Râzînin İslâmî çevrede atomculuk tartışmasına yenilikçi katkısı, hareket ve zamana dayalı atomculuğu destekleyen argümanlar kategorisinin formülasyonunda yatmaktadır. Bu kategori, Aristoteles'in madde, mekân, zaman ve hareketin karşlıklı ilişki içinde olduğu iddiasını kapsamaktadır. Aristotelesçi ve ardından İbn Sînâcı atomculuk eleştirisinin kilit noktası, bölünmez parçalardan sürekli büyüklüklerin oluştuğunu reddetmektir. Râzî, zamanın ve hareketin bölünmez parçalarının birbirlerine "eklenerek" sürekli büyüklükler oluşturduğu şeklindeki formülasyonuyla doğrudan meydan okumayı üstlenmektedir. Filozoflar, ister Râzînnin hareketin sürekliliği görüşünü, bölünmez hareketlerin art arda eklenmesi olarak, isterse de zamanın sürekliliği görüşünü, anların art arda eklenmesi olarak sorgulayabilirler. Onun terimleri kullanımı, ister "sürekli bir varlık gibi" isterse de "süreksiz bir varlık gibi" olsun özenlidir ve Aristotelesçi ve sonrasında İbn Sînâcı eleştiriye karşı koymaktadır. Ancak aynı soru Aristoteles'in eleştirisini takip eden atomculuğun Epikürcü yeniden formülasyona sorulabilir. Ayrık atomculuk ile Aristotelesçi/İbn Sînâcı süreklilik kozmolojileri arasındaki çatışma, tam olarak farklı süreklilik modelleri üzerinedir.

Râzî bu yeni argümanları oluşturmaya ve atomculuğu destekleyen önceki argümanları yeniden biçimlendirmeye ilaveten, aynı zamanda doğrudan İbn Sînâ’nın eleştirisine de cevap vermektedir.

\footnotetext{
$82 \quad$ Fahreddîn er-Râzî, el-Metâlib, 6/43-44.

83 Fahreddîn er-Râzî, el-Metâlib, 6/47.

84 Fahreddîn er-Râzî, el-Metâlib, 6/54.

85 Fahreddîn er-Râzî, el-Metâlib, 6/61.

86 Fahreddîn er-Râzî, el-Metâlib, 6/2.
} 
O, ilk olarak İbn Sînâ’nın Şifầnın Fizik kısmında tartıştığı atomculuğu desteklemek için kelâm argümanlarını değerlendirmekte ve sınıflandırmaktadır. İkinci olarak, İbn Sînâ'nın atomculuğa karşı argümanlarına cevap vermektedir. İlki ile ilgili olarak aşağıdakiler, İbn Sînâ’nın Şifâ adlı eserinin Fizik kitabında tartışmış olduğu atomculuğu desteklemek için Râzînin argümanlara ilişkin analizinin bir özetidir:

ISA1. Bu argüman, şayet bir cisimdeki bileşimlerin tümü ortadan kaldırılsaydı, sonucun atomlar olacağını (geriye atomların kalacağını) iddia etmektedir. Râzî, bunu "mütekellimûnun ikinci delili (hucce)" olarak zikreder ve atomculuğu desteklemek için diğer argümanlar kategorisine yerleștirmektedir. ${ }^{87}$

ISA2. Bu, yarı-mesafeler argümanıdır. Râzî, cisimlerin büyüklüğünün sonluluğuna dayanan argümanlar kategorisinde bunu "birinci delil" olarak zikretmektedir. 0 , bu argümanı Ebü'l-Huzeyl'e atfetmektedir ve iki itiraz sıralamaktadır: birincisi, Nazzâm'ın tafra teorisinin formülasyonuna yol açan itirazıdır. Râzî, bu teorinin yanlışlığının apaçık (ma'lûm fesâd bi'l-bedîha) olduğunu ileri sürmektedir. İkinci itiraz, tıpkı cismin sonsuz derecede bölünebildiği gibi, zamanın da sonsuz derecede bölünebildiğini ve dolayısıyla hareketin başlaması için hiçbir zorluk olmadığını iddia etmektedir. ${ }^{88} \mathrm{Bu}$ itiraz, İbn Sînâ tarafından bu argümanın reddinde öne sürülmüştür. ${ }^{89}$

Râzî, "şayet zamansal sürenin sonsuz parçaları gerçekleşseydi, son zamansal an ulaşılamaz olduğundan, hareket asla sona ermezdi” şeklinde bir iddiayla karşllık vermektedir. Bu nedenle Râzî, mesafenin ve zamanın bölünmesinin sınırlı olması gerektiği sonucuna varmaktadır. ${ }^{90}$

ISA3. Bu, yeryüzünü kaplayan bir hardal tanesinin sonsuz parçaları argümanıdır. Râzî, bunu atomculuğu desteklemek için diğer argümanlar kategorisinde "birinci delil" olarak zikretmektedir. ${ }^{91}$ Râzî, sözlerinde şunu ifade etmektedir:

“íbn Sînâ şöyle dedi: "[bunun inanılması güç bir şey olduğu ve dolayısıyla atomculuk karşıtı görüşün yanlış olduğu şeklindeki] zorunluluk aynı zamanda atomu destekleyenler tarafından da karşı karşıya kalınmıştır. Bundan dolayı, cismin atomlardan oluştuğu şeklindeki görüşleri göz önüne alındığında, bir hardal tanesinde, gökyüzü ve yerlerin yüzeyini kaplayan [atomların] yüzeylerinin olabileceğini varsaymak inanılması güç bir şey olmaz. Bu zorunluluk, onların hepsinin (yani atomcuların ve atom karşıtlarının) üzerine düştüğünden dolayı, o halde artık o inanılması güç bir şey olmaz [sadece atomculuk karşıtı görüş için]."

Ancak Râzî, "atomu kabul ederek, bunun zorunlu olarak yanlış olduğunu biliyoruz" şeklinde bir iddiada bulunmaktadır.

$87 \quad$ Fahreddîn er-Râzî, el-Metâlib, 6/71.

88 Fahreddîn er-Râzî, el-Metâlib, 6/69-71.

89 İbn Sînâ, Physics, 2/304.

$90 \quad$ Fahreddîn er-Râzî, el-Metâlib, 6/71.

91 Bu argümanın Râzî versiyonu, bölünmenin sonucunda ortaya çıan parçalar için, "arş, kürsî, gökler ve yeryüzünün sadece bir kez değil, binlerce kez” kapladığını söylenmesi açısından İbn Sînâ’nınkinden daha renklidir (Fahreddîn er-Râzî, el-Metâlib, 6/75).

92 Fahreddîn er-Râzî, el-Metâlib, 6/75. Bu, doğrudan bir alıntı değildir ancak Râzî’nin İbn Sînâ'nın kelâm argümanına karşı cevabının özetidir (ibn Sînâ, Physics, 2/305). 
ISA4. Bu argüman, "şayet bölünme sınırsız olsaydı, bir hardal tanesinin sonsuz parçaları, dağınkilere eşit olurdu" şeklindeki argümandır. Râzî, cisimlerin büyüklüğünün sonluluğuna dayalı argümanlar kategorisinde bunu "üçüncü delil" olarak zikretmektedir. ${ }^{93}$ Râzî, bir dağın parçalarının, hardal tanesinin parçalarından daha büyük olması gerektiğini, bunun ise her ikisinin de parçalarının sayısının sonlu olmasını gerektirdiğini, aksi takdirde karşılaştırmanın imkânsız olacağını iddia ederek bu argümanı savunmaktadır. Bu nedenle bölünme için bir sınır olması gerekmektedir.

ISA5. Bu, "kendi başına kaim olan bir noktanın, bir atomla aynı olduğu" argümanıdır. Râzî, bunu geometriye dayalı argümanlar kategorisine yerleştirmektedir.

ISA6. Bu, "bölünmez" teğet açı (horn-angle) argümanıdır. Bu argüman, Râzî tarafından zikredilmemiştir.

ISA7. Bu, pürüzsüz bir yüzey üzerindeki bir kürenin hareketi tarafından izlenen bölünmez noktalardan bir çizgi oluştuğu argümanıdır. Râzî, bunu geometriye dayalı argümanlar kategorisinde ilk "delil" olarak zikretmektedir. İbn Sînâ, pürüzsüz yüzey üzerindeki kürenin böyle bir durumunun bilfiil gerçekleștirilebilir olup olmadığını ya da sonuçta ortaya çıkan çizginin, vehim (et-tevehhüm) tarafından varsayılıp varsayılmadığını bilemeyeceğimiz şeklinde bir itiraz öne sürmektedir. ${ }^{94}$ Râzî, "kürenin ve yüzeyin ihtimalini, senin tasvir ettiğin gibi kabul etmiyoruz", çünkü pürüzsüz bir yüzey üzerinde bir kürenin bu şekilde bir tanziminin gerçekleşmesini engelleyen " felsefenin prensiplerine göre bir güçlük yoktur (ġayri müstakîm ale’ uș̂lli'l-felsefe)" şeklinde karşı çıkmaktadır. ${ }^{95}$

Bu atom-karşıtı argümanlara ilişkin Râzî’nin yorumları ve İbn Sînâ'nın itirazlarına karşı cevapları, Metâlib atomculuk tartışmasının, İbn Sînâ'nın atomculuk reddine doğrudan bir cevap olduğunu göstermektedir. Bu, Râzînnin atomculuğu destekleyen argümanlarının sonucunda, (doğrudan İbn Sînâ'yı belirtmeden) açı̆̆a kavuşturulmuştur:
“Birçok kesin ve tartışmasız yollarla (el-vücûhül'-kat'i ve'l-yakînî̀), şayet cisimler sonsuz bölünebilseydi, onların sonsuz parçalardan oluşması gerekeceğini açılkardık. Bu argümanları, cisimlerin bilfiil sonsuz parçalardan oluşturulmasının imkânsız olduğunu göstermek için belirttik. Dolayısıyla onların sonsuz bölünebildiği şeklindeki öncülün yanlış olması gerekmektedir. Böylelikle bu argümanlar, filozofların öğretilerini reddetmeye yardımcı olmuştur."

Râzî, atomculuğu destekleyen argümanları tartıştıktan sonra atomculuğu reddeden argümanlara geçmektedir. O, bu argümanları temasa (mümâsse), hız değişimlerine, sıçrama doktrinine (tafra), harekete, cismin zâtına ve onun uzamsal yer kaplamasına dayananlar şeklinde sınıflandırmaktadır. Bu argümanların çoğu, İbn Sînâ'dan kaynaklandığını gördüğümüz Mebâhis'te daha önce getirdiği argümanlarla uyumludur. Ancak Mebâhis'teki tartışmanın aksine Metâlib, atom-karşıtı argümanların hipotezlerini, zaman zaman itirazlarda bulunarak, zaman zaman da argümanları çürüterek uzun uzadıya detaylandırmaktadır. Mesela, RMb2 ve ISB9‘a ( iki uca

93 Fahreddîn er-Râzî, el-Metâlib, 6/71-72.

94 İbn Sînâ, Physics, 2/308-309.

95 Fahreddîn er-Râzî, el-Metâlib, 6/71.

96 Fahreddîn er-Râzî, el-Metâlib, 6/73. 
yerleştirilen ve sonra ortadaki boş alanı işgal etmek için eş zamanlı hareket eden iki atomun üzerinde bulunduğu üç atom sırasına) karşıllk gelen argümanlardaㄱ Râzî, iki atomun eş zamanlı hareketinin, bir atom uzunluğunda olan ortadaki boşluğun bölünme imkânı şartına bağlı olduğu şeklinde bir itirazda bulunmaktadır. Ancak bu şartın yerine getirilmesi imkânsız olduğundan, "uçlara yerleştirilen iki atomun [eş zamanlı hareketinin] imkânının şartı yok olur ve bu şart yok olduğu zaman, sonrasında şart tarafından gerektirilen şey (yani ortadaki boş alana hareket) de imkânsız olur." ${ }^{98}$ Başka bir yerde Râzî, atomculuğa karşı olan argümanların hatalı olduğuna ve doğru olmadığına (hucce muğâlatıyya ve leyse hucce hakîkiyye) ve onların sonuçlarının yanlış olduğuna (netîce bâț̣la) hükmeder. Çünkü onlar doğru olsaydı, "cisimler bilfiil sonsuz parçalardan oluşurdu." ${ }^{99}$ Açık bir şekilde Râzînin Metâlib'deki tutumu, atomculuğu hem destekleyen hem de reddeden argümanları tartışmasına rağmen kararsızlık sayılmaz. Bu nedenle Râzînin hayatının sonuna doğru Metâlib'de atomculuğu desteklediği şeklindeki Zerkân'ın ve Setia'nın iddiasına katılıyorum. Ayrıca Râzînin atomculuğu desteklemek için getirdiği argümanların, İbn Sînâ’nın Şifâ adlı eserinin Fizik kitabında ve diğer eserlerinde kelâm atomculuğu reddine doğrudan bir cevap olduğu açıktır.

Baffioni'nin “Râzî’nin olgunluk dönemi eserlerinden biri” olduğunu düşündüğü el-Erbaîn fî usûli’ddîn'in bir incelemesi, atomculuğu destekleyen argümanlarının, kısaltılmış bir biçimde olsa da Metâlib'dekiler ile aynı olduğunu göstermektedir. ${ }^{100}$ Metâlib gibi, Erbaîn de esas olarak teolojik bir metindir, ancak atomculuğu ve boşluğu destekleyen bölümler içermektedir. Atomculuk hakkındaki bölüm, hem atomculuk taraftarlarının hem de karşıtlarının argümanlarına yer vermektedir. Atomculuk-karşıtı argümanlar, şu sözlerle ortaya konmaktadır: "filozoflar vehim tarafından bölünmenin sınırsız olduğunu iddia etmişlerdir. Onlar, aşağıdaki argümanları (lit. yollar - vücûh) takip ederek bunu kanıtlamışlardır". Râzî, bölünme için bir sınır olduğuna karşı on argüman zikrettikten sonra ${ }^{101}$ şu sonuca varmaktadır:

“Atomculuğu reddetmek için argümanları, bu on argümanla sınırlayalım. Yalnızca bu konu için ayrılmış bir kitap yazdık. Derinlemesine araştırma yapmak isteyen kimse, bu kitaba başvurabilir. [Burada] biz tüm bu şüphelere tek bir yanıtla cevap vereceğiz ve bu kitap için özel yanıtlar bırakacağız.

Daha sonra biz şöyle deriz: Bu argümanların tümü, atomun iki kenarından her birinin, diğer kenarda bulunmayan belirli bir özellik ile nitelenmesi gerektiği şeklinde ortak bir varsayıma (şey) sahiptir. Ancak bu, sonsuz bölünme bilfiil gerçekleştiği zaman gerekli olan bir şeydir (mâna). Filozoflar bunun ne mümkün olduğuna inanırlar, ne de ortaya attıkları şüphelerin sonuçlarını kabul ederler. Onlar, bu argümanların sonuçlarına değil, yalnızca potansiyel olarak bölünebilirliğe inanırlar. Dolayısıyla bu argümanların tümünün geçersiz ve batıl olduğu gerçeği sabit olmuştur."102

Fahreddîn er-Râzî, el-Metâlib, 6/88.

Fahreddîn er-Râzî, el-Metâlib, 6/88.

Fahreddîn er-Râzî, el-Metâlib, 6/93.

Fahreddîn er-Râzî, el-Erbaîn, 2/6-11. Râzî, hareket, zaman, geometrinin ilkeleri ve cisimlerin büyüklügünün sonluluğundan kaynaklanan argümanlar zikretmektedir.

101 Fahreddîn er-Râzî, el-Erbaîn, 2/11-16.

102 Fahreddîn er-Râzî, el-Erbaîn, 2/17. 
Râzî, Erbaîn'i yazdığı zaman, atomculuk hususunda artık kararsız olmadığı açık bir şekilde görülmektedir. ${ }^{103}$

Sonuç olarak Râzî, İbn Sînâ'nın Şifâ adlı eserinin Fizik kitabındaki ve diğer eserlerindeki kelâm atomculuğu eleştirisine tamamen aşinaydı. Muhtemelen o, entelektüel kariyerinin erken aşamasında bu eleştiriyi ikna edici buldu. Ancak daha sonra ve kesin bir şekilde hayatının sonuna doğru atomculuğa bağlılığını doğruladı. Bunu, İbn Sînâ’nın eleştirisine doğrudan karşılık veren argümanlar ve itirazlar formüle ederek savundu.

Klasik Yunan doğa felsefesi için Epikür ve İslâmî doğa felsefesi için Râzî, ilki Aristoteles'e karşılık olarak, sonraki İbn Sînầya cevaben selefleri için atomculuğu yeniden formüle etmişlerdir. Epikür'ün yeniden formülasyonu, sonraki nesil doğa filozofları arasında son derece etkiliydi. Aynısı, Râzî’nin atomculuğu yeniden formülasyonu için de söylenebilir mi? O, Epikür'e benzer mi? Kısa bir şekilde cevap vermek gerekirse, Râzînin atomculuğu desteklemek için yeniden formülasyonu ve yeni argümanları, sonraki nesil âlimler tarafından iyi bilinen ve tartışılan bir husustu. Bunlar mesela, yüzyıllarca kelâm çalışmaları için ekol bir metin olan el-Îĉ̂̀nin etkili elMevâkıffí ilmi'l-kelâm'ında bulunmuştur. Ancak bu soruya detaylı bir cevap, on dördüncü yüzyıldan sonra yazılan metinlerdeki atomculuk tartışmalarının kapsamlı bir incelemesini gerektirmektedir. Bu görev başka bir firsatı beklemelidir.

103 Ancak Baffioni'nin vardı̆̆ı sonuç; Râzînnin atomculuk aleyhindeki Peripatetik argümanları eleştirirken, temelde ortaya çıkardığı geometrik zorluklardan dolayı kelâm atomculuğunun bir destekçisi olmadığıdır. (Atomismo, 275). 


\section{Kaynakça}

Adang, Camilla vd. Basran Mu'tazilite Theology: Abū 'Alī Muhammad ibn Khallād's Kitāb al-Usūl and its Reception. Leiden: Brill Academic Publishers, 2011.

Altaş, Eşref. “Fahreddîn er-Râzî̀nin el-Cevherü'l-ferd Adlı Risalesinin Tahkiki ve Tahlili”. Nazariyat İslâm Felsefe ve Bilim Tarihi Dergisi 2/3 (Ekim 2015), 75-170.

Baffioni, Carmela. Atomismo et Antiatomismo nel Pensiero islamico. Naples: Istituto Universitario Orientale, 1982.

Beyhakî, Ali b. Zeyd. Tetimmetu sivani'l-hikme. ed. R. el-Acem. Beyrut: y.y., 1994.

Bostock, David. "Aristotle on continuity in Physics VI". Aristotle's Physics: A Collection of Essays. ed. L. Judson. 179-213. London: Oxford University Press, 1995.

Cüveynî, İmâmü'l-Haremeyn. eş-Şâmil fî usûli'd-dîn. ed. A. en-Neşşâr vd. İskenderiye: Münşeetü'lMaârif, 1969.

Dhanani, Alnoor. The Physical Theory of Kalām. Leiden: E. J. Brill, 1994.

Dhanani, Alnoor. "Problems in Eleventh-Century Kalām Physics". Bulletin of the Royal Institute of Interfaith Studies 4/1 (2002), 73-96. https://dergipark.org.tr/tr/download/article-file/179985

Dhanani, Alnoor. "Rocks in the Heavens!? The encounter between 'Abd al-Jabbar and Ibn Sina". Before and After Avicenna. ed. D. Reisman. 127-144. Leiden: Brill, 2003.

Frank, Richard M. Al-Ghazāli and the Ash'arite School. Durham ve London: Duke University Press, 1994.

Furley, David. Two Studies in the Greek Atomists. Princeton: Princeton University Press, 1967.

Gazzâlî, Ebû Hamîd Muhammed. Makâsılü'l-felâsife. ed. M. Kurdī. Kahire: y.y., 1936.

Gazzâlî, Ebû Hamîd Muhammed. The Incoherence of the Philosophers. çev. M. Marmura Provo, UT: Brigham Young University Press, 1997.

Gianotti, Timothy. Al-Ghazâl’’s Unspeakable Doctrine of the Soul. Leiden: Brill, 2001.

Heemskerk, Margaretha. Suffering in Mu'tazilite Theology. Leiden: Brill, 2000.

İbn Sînâ, Ebû Ali el-Hüseyin. el-işârât ve't-tenbîhât. ed. S. Dünya. 4 Cilt. Kahire: Dârü'l-Maârif, 19571960.

İbn Sînâ, Ebû Ali el-Hüseyin. Kitâbü’n-Necât. ed. M. Fahri. Beyrut: Dârü'l-Âfâkı'l-Cedîde, 1985.

İbn Sînâ, Ebû Ali el-Hüseyin. The Physics of the Healing. çev. J. McGinnis. 2 Cilt. Provo: Brigham Young University, 2009.

Lane, Edward William. An Arabic-English Lexicon. 8 Cilt. Beyrut: Mektebetu Lübnan, 1968.

Marmura, Michael. "Avicenna and the kalām”. Zeitschrift für Geschichte der arabisch-islamischen Wissenschaften 7 (1991), 172-206. 
Mayer, Toby. Keys to the Arcana: Shahrastāni’s Esoteric Commentary on the Qur'ān. London: Oxford University Press, 2009.

Monnot, Guy. "al-Shahrastānī”. Encyclopedia of Islam (New Edition). ed. P. Bearman vd. Leiden: Brill, 2012.

Murâd, Said. İbn Metteveyh ve ârâ'uhu'l-kelâmiyye ve'l-felsefiyye. Kahire: Mektebetü'l-Enclû elMisriyye, 1991.

Pyle, Andrew. Atomism and its Critics. Bristol: Bloomsbury Publishing Plc, 1995.

Râzî, Fahreddîn. el-Erbaîn fî usûli'd-dîn. thk. Ahmed Hicâzî es-Sekkâ. 2 Cilt. Kahire: Mektebetü'lKülliyati'l-Ezheriyye, 1986.

Râzî, Fahreddîn. el-Işâââ fí ilmi'l-kelâm. ed. H. Muhammed. Kahire: Mektebetü'l-Ezheriyye li't-Türas, 2009.

Râzî, Fahreddîn. el-Mebâhisü'l-meşrikıyye. ed. M. el-Bağdâdî. 2 Cilt. Beyrut: Dârü'l-Kitâbi'l-Arabi, 1990.

Râzî, Fahreddîn. el-Metâlibü'l-âliye. thk. Ahmed Hicâzî es-Sekkâ. 8 Cilt. Beyrut: Dârü'l-Kitâbi'l-Arabi, 1987.

Setia, 'Adi. "Atomism versus hylomorphism in the kalam of al-Fakhr al-Din al-Razi: a preliminary survey of the Matalib al-'Aliyyah". Islam and Science 4/2 (2006), 113-140. https://www.thefreelibrary.com/Atomism+versus+hylomorphism+in+the+kalam+of+al-Fakhr+alDin+al-Razi\%3A+a...-a0157034131

Setia, 'Adi. The pyhsical Theory of Fakhr al-Dīn al-Rāzì. Malezya: International Islamic University Malaysia, Doktora Tezi, 2005.

Sorabji, Richard. "Chapter twenty-five: atoms and divisible leaps in Islamic Thought". Time, Creation, and the Continuum: Theories in Antiquity and the Early Middle Ages. 384-402. Ithaca: Cornell University Press, 1983.

Şehristânî, Ebü'l-Feth Tâcüddîn. Nihâyetü'l-ikdâm. ed. A. Guillaume. Londra: Oxford University Press, 1934.

Şehristânî, Ebü'l-Feth Tâcüddîn. Struggling with the Philosopher: a Refutation of Avicenna's Metaphysics. A new Arabic edition and English Translation of Muhammad b. 'Abd al-Karïm b. Ahmad al-Shahrastānī's Kitāb al-Musāra'a. ed. ve çev. Wilferd Madelung - Toby Mayer. Londra: Brill, 2001.

Wisnovsky, Robert. "One aspect of the Avicennan turn in Sunni Theology", Arabic Sciences and $\begin{array}{llll}\text { Philosophy 14/1 2004), } & \text { 65-100. }\end{array}$ file:///C:/Users/panter/Downloads/One_aspect_of_the_Avicennian_turn_in_Sunn_theology.pdf

Zerkân, Muhammed Salih. Fahreddîn er-Râzî ve ârẩuhu'l-kelâmiyye ve'l-felsefiyye. Kahire: Dârü'l-Fikr, 1963. 